\title{
Assessing the Trace Metal Content of Groundwater in the Bakassi Peninsular, Onshore Rio del Rey, Akwa-Mundemba, Cameroun
}

\author{
Richard Ayuk II Akoachere ${ }^{*}$ (i), Takahiro Hosono², Thomson Areakpoh Eyong1, \\ Marcelle-Carole Pami Ngassam ${ }^{3}$, Tom Tabi Oben 4 \\ ${ }^{1}$ Department of Geology, University of Buea, Buea, Cameroon \\ ${ }^{2}$ Priority Organizations for Innovation and Excellence, Kumamoto University, Kurokami, Japan \\ ${ }^{3}$ Department of Agricultural and Environmental Engineering, Pan African University/University of Ibadan, Ibadan, Nigeria \\ ${ }^{4}$ Department of Agronomy and Applied Molecular Sciences, University of Buea, Buea, Cameroon \\ Email: *r.akoachere@ubuea.cm
}

How to cite this paper: II Akoachere, R. A., Hosono, T., Eyong, T. A., Ngassam, M.-C. P., \& Oben, T. T. (2019). Assessing the Trace Metal Content of Groundwater in the Bakassi Peninsular, Onshore Rio del Rey, Akwa-Mundemba, Cameroun. Journal of Geoscience and Environment Protection, 7, 23-48.

https://doi.org/10.4236/gep.2019.710003

Received: September 4, 2019

Accepted: October 18, 2019

Published: October 21, 2019

Copyright $\odot 2019$ by author(s) and Scientific Research Publishing Inc. This work is licensed under the Creative Commons Attribution International License (CC BY 4.0).

http://creativecommons.org/licenses/by/4.0/

\begin{abstract}
The present work assesses the trace metal content in groundwater from Akwa-Mundemba, Bakassi Peninsular in Cameroon. 12 groundwater samples were analyzed using Inductively Coupled Plasma Mass Spectroscopy ICP-MS. Field measurement of physicochemical parameters was determined. R-mode statistical analysis; Pearson's Correlation Analysis (PCA) together with Hierarchical Cluster Analysis (HCA) between the trace metals and the physico-chemical parameters was carried out. Ten indices were determined: Four trace metal hazard indices; the average daily dose ADD (2.5E-07 to 0.2)) carcinogenic risks $\mathrm{CR}(2.1 \mathrm{E}-06$ to $9.9 \mathrm{E}-04)$ and the non-carcinogenic risk hazard quotient HQ (5.7E-04 to 0.78) which yields the hazard indices HI (0.1 $0.78)$, and six trace metal pollution indices; Degree of contamination DC (-13.53 to -11.02), Enrichment factor EF (0.26 - 35.47), Ecological risk factor Er (-29.92 - 7.04), Potential ecological risk index RI (-61.2-43.43), Pollution load index PLI (-0.01 - 0.04) and Geo-accumulation index Igeo (4.8E-09-3.0). From health risk indices and pollution evaluation indices on trace metals, the groundwater in Akwa-Mundemba area is safe for drinking. The enrichment factors show that the sources of the trace metals are from geogenic and anthropogenic processes. Arsenic, Lead and Vanadium are enriched although they are below the hazard risk values; this shows they have pollution potential that could be attributed to weathering and agricultural wastes. The severity of metal toxicity is governed by several factors, such as dose, nutrition, age, and
\end{abstract}


even life style. Therefore, these low trends might not guarantee the complete absence of human health risks. Generally, from risk assessment on trace metals using risk indices in the analyzed groundwater samples might not cause any health risk. However, due to an increasing level of environmental pollution that might be imposed by increasing human activity in this area, groundwater sources might become a potential sink of contaminants; this is significant reason that makes constant monitoring, implementation and treatment of groundwater for drinking purposes necessary.

\section{Keywords}

Trace-Metals, Pollution Indices, Hazard Indices, Bakassi-Peninsular, Rio-del-Rey, Cameroun

\section{Introduction}

Akwa-Mundemba area is found between, $4.450 \mathrm{~N}-4.955 \mathrm{~N}$ and $8.500 \mathrm{E}-8.950 \mathrm{E}$ in the Bakassi Peninsular, Ndian Division of the South West Region in Cameroon as in Figure 1. Groundwater is the main resource for drinking in the area through springs, handdug wells and boreholes. The study area has a surface area of 1.557 kilometres squares. Mundemba shares boundaries with Eyumojock in

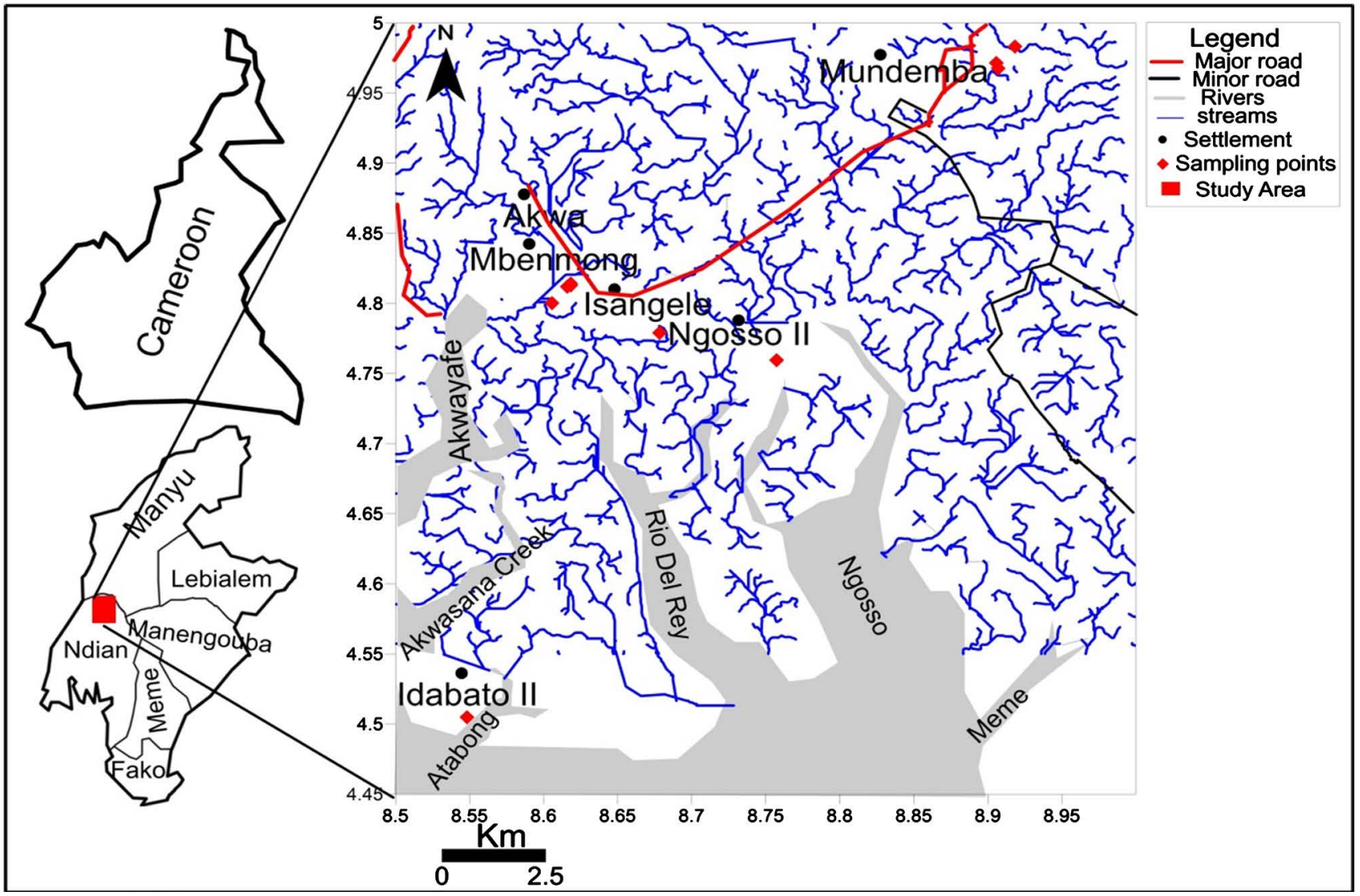

Figure 1. Location map for measurements and sample collection. 
North, Isangele and Ekondo Titi in the South, Toko, Konye and Dikome-Balua in the East and Nigeria in the West. It is a gateway to Nigeria and other countries.

This area is an agro-industrial zone of fishing, palm oil, rubber and banana plantations, all of which are exported and dependent on groundwater. There are petroleum companies exploiting oil off-shore in the area. The presence of industries has led to unprecedented population growth and urbanization around this area resulting in a high demand for water that has now exceeded supply. The assessment of trace metal quality of springs, dug wells and borehole water exploited for consumption by more than $90 \%$ of inhabitants of this area is sparse. Therefore a series of health risks and pollution risks associated with elevated trace metals concentrations in groundwater may arise if the trace metal concentrations of groundwater in this area are high (Mehri \& Marjan, 2013).

Trace metals are chemical components found in low concentrations, in mass fractions of ppm or less, in water, organisms and soil (Akoachere et al., 2019). Some trace metals are essential as micronutrients $\mathrm{Cu}, \mathrm{Fe}, \mathrm{Mn}, \mathrm{Ni}$ and $\mathrm{Zn}$ for life processes in plants and microorganisms, while others $\mathrm{Cd}, \mathrm{Cr}$ and $\mathrm{Pb}$ have no known physiological activity, but are proven detrimental beyond a certain limit which is very much narrow for some elements $(\mathrm{mg} / \mathrm{L})$ like $\mathrm{Cd} 0.01, \mathrm{~Pb} 0.10$ and $\mathrm{Cu}$ 0.050 (Verma \& Dwivedi, 2013). These toxic metals, unlike some organic substances, are not metabolically degradable and have the tendency to bio-accumulate in tissues of living organisms over time which can cause death or serious health threats (Akoachere et al., 2019). The presence of trace metal species in groundwater can be of geogenic or anthropogenic origin. Natural or geogenic contamination occurs when the weathering of minerals in rocks results in the entry of heavy metals into the environments and water bodies are retained in the groundwater/soil and do not readily leach out; accumulate through geological processes, enter the food chain through ingestion and ultimately pose a threat to humans, animals and plants. By ion exchange, precipitation, dissolution or mixing, trace metal ions contained in the rocks are introduced into the water. These metals exist in water as colloidal, particulate and dissolved species. Anthropogenic contamination occurs through the development of industrial agriculture, mining, smelting and other industrial activities. Metallic elements have a significant role in increasing the degradation of water quality through human activities; industrial-household wastes, thermal power plants, mining, exhaust emissions, application of fertilizers, pesticides and insecticides. Trace metals pose a severe threat to human and environmental health since these elements are toxic at low concentrations and pollution caused by these heavy metals is long-term and irreversible; cumulative. Trace metals are increasingly being found in groundwater sources. The exposure to trace metal contamination and associated health risk levels of the population in Akwa-Mundemba has not been investigated hence; the quantification of trace metals for suitability of the groundwater resources for drinking, domestic and agro-industrial uses is of public health and scientific concern. It has been recognized for many years that the concentrations 
of metals found in coastal areas, whether they are in the dissolved or particulate phase may be derived from a variety of anthropogenic and natural sources. In most circumstances, the major part of the anthropogenic metal load in the marine sediments and organisms has a terrestrial source from mining and intensive aquaculture and municipal wastewaters, untreated effluents, harbor activities, urban and agricultural runoff along major rivers, estuaries and bays. These elements are: Antimony, Arsenic, Boron Barium, Bromine, Cadmium, Cesium, Chloride, Cobalt, Copper, Fluoride Iodine, Iron, Lead, Lithium, Manganese, Mercury, Molybdenum, Nickel, Phosphorus, Rubidium, Selenium, Strontium, Uranium, Vanadium and Zinc.

\subsection{Climate}

This area has an equatorial climate with two main seasons: the dry and the wet seasons. The dry season is usually very short and runs from November to February while the wet season is long and it's between March to October. The mean monthly temperature ranges from $23^{\circ} \mathrm{C}$ to $30^{\circ} \mathrm{C}$ (Cameroon Pamol Plantation, Cameroon, 2005-2008).

\subsection{Relief}

The study area is composed of a stretch of hilly topography. It is made of gentle slopes gradually increasing from the south west coast of river Ndian to the undulating slopes of the Rumpi Hills forest reserve in the south west, stretching right up to Toko sub division. Another stretch of undulating hilly topography is found in the south east of the area, around the northern part of the Rumpi forest reserve. The highest point here is a hill with altitude of $505 \mathrm{~m}$ (Mundemba Monographic Study, 2010).

\subsection{Hydrology}

The Akwa-Mundemba area is characterized with numerous streams, spring and major rivers; the Akwa Yafe River, Dibonda and the Mundemba rivers. Most of the rivers and streams take their rise from the Rumpi hills and the northern part of the Korup national park (KNP). Rivers and streams that take their rise from the Rumpi hills and flows towards the northern section of the proposed council forest while those that take their rise from the northern part of the KNP flow in a southern direction of the park. The streams combine to form the Mana and Mbo's rivers that finally drain into river Ndian and the Atlantic Ocean while the main stream Mossambi converges with river Lokeri and drains into the Dibonda river, which empties into the Atlantic Ocean.

\subsection{Geology}

Cameroon's geology is made of different rock types.

These are:

1) Precambrian basement rocks covering about $77 \%$ of Cameroon and underlie; 
2) Sedimentary rocks covering $9 \%$ are of Cretaceous to the Cenozoic Era intruded in some areas by;

3) The Tertiary to recent volcanics covering $10 \%$ found generally along the Cameroon Volcanic Line (CVL);

4) Over a, b and c, above along major river channels, deltas and seashores are recent alluvium that make up some $4 \%$.

Bakassi Peninsula is found in the Rio del Ray basin (Coastal basin) which is one of the Equatorial Atlantic marginal basins in the Gulf of Guinea, covering $2500 \mathrm{sq} \cdot \mathrm{km}$ and dipping ocean-wards with about $6000 \mathrm{~m}$ thick of sediments ranging from Cretaceous to Recent. The basin proper is bordered to the west and northwest by the contemporaneous Niger Delta Basin, limited to the south by the Island of Bioko, the north by the Rumpi Hills and to the east by the Cameroon Volcanic Line (CVL) separating the Rio del Ray basin from the Douala Basin.

The Rio del Ray basin and the Douala basin are genetically related and were linked together constituting one composite basin, which was itself attached to the Niger Delta in Nigeria. There are four Formations of the Rio del Ray basin; Akata, Agbada, Benin and the Isongo formations averaging a depth of $2.5 \mathrm{~km}$.

The Akata Formation is about $600 \mathrm{~m}-6000 \mathrm{~m}$ thick. The sands are continental slope channel-fills and turbidities.

The Agbada Formation overlies the Akata Formation and consists of interbedded sand and shales with thickness of about $300 \mathrm{~m}-4500 \mathrm{~m}$. The coarse clastic beds are the oil reservoirs of up-to-date discovered oilfields.

The Benin Formation is the topmost Tertiary sequence of the Niger Delta and continues eastwards into the Rio del Ray basin as a fringe zone of shales diapirs, sandy clays, dark-green sandstones, lignites and fragments of volcanic rocks. The Benin Formation has a thickness of about $1890 \mathrm{~m}-2300 \mathrm{~m}$ at the center.

The Isongo Formation is encountered mostly south-east of the Rio del Ray basin and represent a mixed phase of marine shales and fan sands.

The Formations in the Rio del Ray basin that outcrop onshore are Aptian to Albian Mundeck, coarse fluvial sandstone and the late cretaceous Mungo and Logbaba, shallow marine limestones, sandstones and shales which are overlain unconformably by Tertiary non marine sands and silts. Offshore the sequence above the unconformity is Eocene to recent, the Akata Formation, diachronous pro-deltaic shales are overlain by the Agbada, deltaic front sandstones, shales and the Benin, fluvial sands. The Rio del Ray basin also contain some features of the Cameroon Volcanic Line (CVL), an alignment of volcanic massifs trending north-south from the island of Pagalu to lake Tchad, consisting of a hosts and grabens and is an example of intraplate volcanism (Fitton, 1980; Fitton \& Dunlop, 1985; Halliday et al., 1988, 1990). The CVL is a "Y" shape long chain of Tertiary to Recent Volcanic complexes with a general NE-SW orientation and spreads from the South Atlantic into the interior of Africa. Amongst the 60 volcanic craters that litter the CVL, Mount Cameroon is the most active. The CVL extends more than $900 \mathrm{~km}$ across Cameroon from Bui and Adamawa plateau in 
the north of mount Cameroon and Equatorial Guinea (Poudjom Djomani et al., 1997), it then continues for another $700 \mathrm{~km}$ through the Atlantic island of Principe, Sao Tome and Palagu (Ubangoh, 1998). The CVL was initiated by an upwelling mantle plume since the onset of the continental breakup in the early cretaceous. It generally consists of basalts to ryholite nephelinites, phenolites and trachytes with volcanic rocks found within the volcanoes (Halliday et al., 1988). The continental volcanoes are Mount Fako, Rumpi hills, Manengouba, Bambuotus, Oku and the volcanic rocks of Kapsiki plateau and the Benue valley (Nono et al., 2004). The oceanic part is made up of Annabon, Sao-Tome, Bioko and Principi (Ngako et al., 2006). The continental sector of the CVL seems to follow old suture zones between two seismically and paleomagnetically distinct lithospheric blocks (Fairhead \& Binks, 1991; Smith \& Livermore, 1991). The major rock formations in Bakassi Peninsular onshore around Mundemba are; granite, gneiss, metasediments (Cretaceous; Tertiary sediments), volcanics, and Recent alluvium as in Figure 2.

The Cretaceous-Tertiary sediments vary according to the environment of deposition and are essentially clastic, consisting of sands, sandstone, and conglomerates with subsidiary clays, shales, marls and lignites outcropping beyond the southern catchments' limits with a thickness of about 68 meters. The Tertiary-Quaternary basaltic lavas associated with the Cameroon Volcanic Line, as part of the major Foumban shear zone, intruded the sediments during the Miocene (Dumort, 1968). This magmatic activity resulted in extensive lava flows that formed the Rumpi hills in the north and intruded the sediments in the south. These extrusive events lapsed for sufficient time allowing a substantial

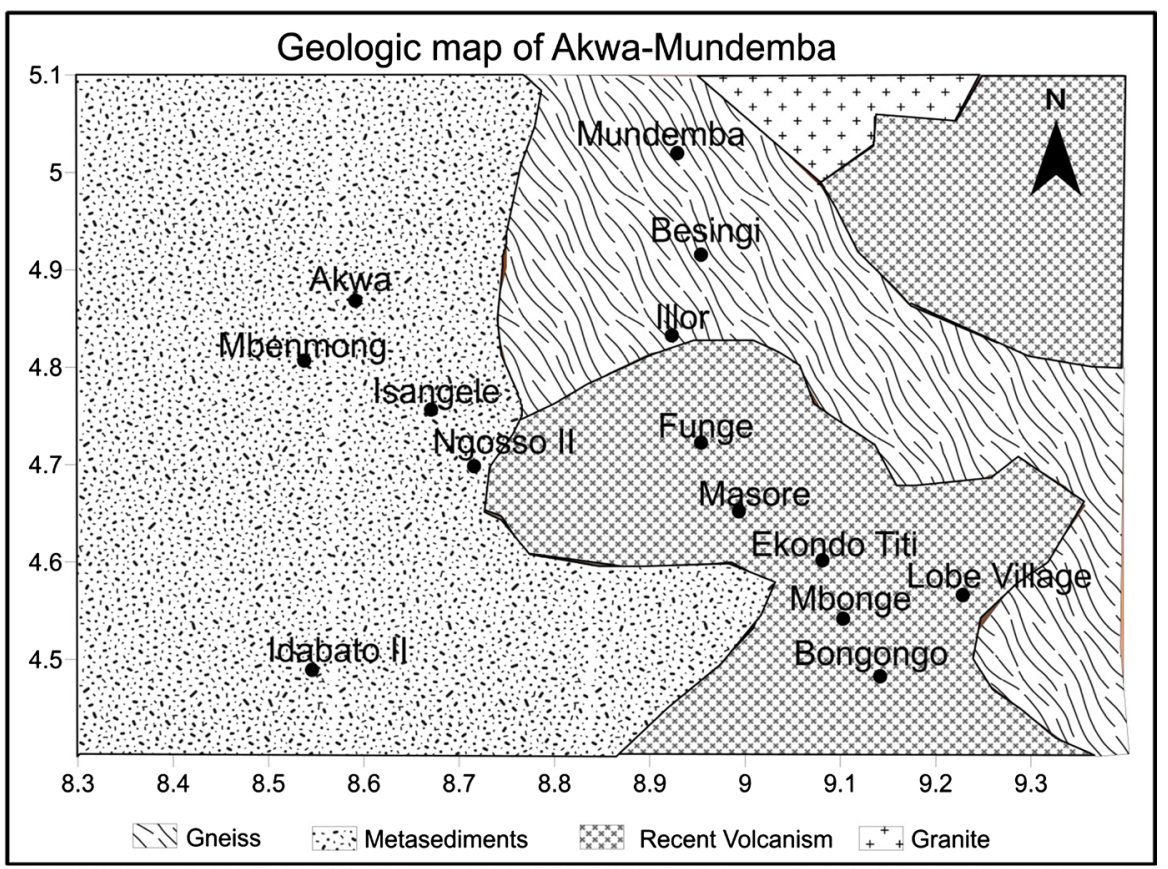

Figure 2. Geologic map of study area made up of four rock types; gneiss, metasediments, recent volcanism and granites. 
layer of ash and basaltic lava flows to become interbedded with the extensive alluvium, deltaic and lacustrine deposits and in the study area columnar basalts are common intrusive. Recent alluvium is being deposited along the present coastline and margins of the delta of the Akwa Yafe River.

\subsection{Hydrogeology}

The aquifer(s) in this area are heterogeneous intercalation of fluvio-deltaic and marines conglomerates, sands, sandy clays, lateritic silts, silty clays, clayey sands, shales and marl lenses. Also the fractured gneisses and granites constitute good aquifers in some areas around Toko, Mundemba Town etc.

The study aims to improved knowledge on the occurrence of trace metals in groundwater in Akwa-Mundemba, which will provide information on the concentration ranges, act as basis for future regulations on trace metals in drinking, provide estimates of the contribution of groundwater to overall trace metal intake, provide baseline on trace metals if challenges arise in the future, estimate the health hazard and pollution indices of trace metals in groundwater of Akwa-Mundemba area.

\section{Materials and Methods}

\subsection{Sample Collection, Pre-Treatment and Chemical Analysis}

Twelve groundwater samples were collected from 12 pre-selected wells, boreholes and springs. Site selection was based on spatial distribution of the wells, boreholes, springs and population. At each site, groundwater temperature, electrical conductivity, total dissolve solids and $\mathrm{pH}$ value were measured in situ, using portable field $\mathrm{pH}, \mathrm{EC}$ and TDS meters as shown in Table 1.

Prior to sampling, the pre-cleaned sample bottles were rinsed with the sample water. The well water was withdrawn with the use of a $50 \mathrm{ml}$ syringe, and then filtered through the $0.2 \mu \mathrm{m}$ mixed cellulose ester filter into $50 \mathrm{ml}$ high-density polyethylene HDPE containers. The sample was preserved by acidifying to $\mathrm{pH}<$ 2 by adding nitric acid and sealed using a permanent tape. The samples were labelled and put into the sample bottle collection bag. The filtered groundwater samples were later shipped to the Activation laboratory in Canada for trace metal analysis by Inductive Coupled Plasma Mass Spectrometer ICP-MS.

\subsection{Hazard Identification}

It involves the identification of the chemical of concern and documenting its toxic effects on human beings after field mapping. It also involves the characterization of potential contaminants and their relative mobilities (Paustenbach, 2002) as shown in Table 2.

\subsection{Exposure Assessment}

This is the process of measuring or estimating the intensity, frequency and duration of human exposures to an environmental agent (Paustenbach, 2002). The 
Table 1. Field equipment, softwares, their specifications and functions used in the study.

\begin{tabular}{|c|c|c|}
\hline Equipment/Softwares & Specifications & Functions \\
\hline Bike & Commercial Bikes (Bensikin) & To transport fieldworkers to wells \\
\hline GPS & GARMIN GPSMAP $60 \mathrm{csx}$ & To measure longitude, latitude and elevation of wells \\
\hline EC Meter & Hanna Hi 98304/Hi98303 & To measure electrical conductivity of water \\
\hline pH Meter & Hanna Hi 98127/Hi98107 & To measure $\mathrm{pH}$ of water \\
\hline Measuring Tape & Weighted Measuring Tape & Measurement of well diameter and depth. \\
\hline Digital Thermometer & Extech $39240\left(-50^{\circ} \mathrm{C}\right.$ To $\left.200^{\circ} \mathrm{C}\right)$ & To measure water temperature \\
\hline Total Dissolved Solid & Hanna HI 96301 & To measure total dissolved solids \\
\hline Water Sampler & Gallenkampf $500 \mathrm{ml}$ & To collect water sample from well \\
\hline Syringe & $50 \mathrm{Ml}, 100 \mathrm{Ml}$ Polystyrene & Acidification and filtration of sample \\
\hline Nitric Acid & 98\% Pure Nitric Acid & Sample preservation by acidifying to $\mathrm{pH}<2$ \\
\hline Filter & Cellulose Ester Filter $0.2 \mu \mathrm{m}$ & Filtration of sample \\
\hline Sample Bottles & Polyethylene (HDPE) $50 \mathrm{ml}$ & To hold sample for onward transmission to laboratory \\
\hline Sealing Tape & Permanent Tape and Marker & Sealing of sample bottle and labeling for transmission to the laboratory \\
\hline IBM SPSS Statistics & Version 24.0 & Statistical analysis for PCA \\
\hline Global Mapper & Version 11 & GIS Geolocation of wells \\
\hline Surfer Golden Software & Version 12 & GIS plotting contours for spatial distribution \\
\hline
\end{tabular}

Table 2. Trace metals and their effects (Akoachere et al., 2019).

\begin{tabular}{cl}
\hline Component & \\
\hline $\mathrm{Zn}$ & Zinc suppresses copper and iron intake causing peripheral neuropathy. \\
$\mathrm{Co}$ & Active in vitamin $\mathrm{B} 12$ and in chemical reactions. Excess causes hearth failures. \\
$\mathrm{Cu}$ & Excess leads to acute gastrointestinal problems. \\
$\mathrm{Cr}$ & Excess may result in renal failures. Excess of $\mathrm{Cr}^{+6}$ is carcinogenic. \\
$\mathrm{Mn}$ & Manganese toxicity result in neurological disorder; manganism, with symptoms of \\
$\mathrm{Cd}$ & Cadmium compounds are known human carcinogens. \\
$\mathrm{V}$ & Vanadium causes albumin in urine. \\
$\mathrm{Ni}$ & Nickel is carcinogenic and causes neurological deficits. \\
$\mathrm{As}$ & Arsenic causes cancer of the skin, lungs, liver and bladder. \\
$\mathrm{Sb}$ & Antimony causes gastrointestinal problems, kidney damage or liver damage. \\
$\mathrm{Al}$ & Aluminium causes neurotoxicity. \\
$\mathrm{Pb}$ & Lead is a carcinogen affecting every organ and system in the body.
\end{tabular}

main exposure pathway taken into consideration in this study was intake of the metals through water consumption. The daily environmental exposures to metals were assessed for carcinogenic and non-carcinogenic elements.

The intake of metals through ingestion of groundwater was calculated using 
Equation (1) (Hu et al., 2012).

$$
\mathrm{ADD}=\frac{\mathrm{C} \cdot \mathrm{IR} \cdot \mathrm{ED} \cdot \mathrm{EF}}{\mathrm{BW} \cdot \mathrm{AT} \cdot 360}
$$

where;

- ADDs is Exposure duration (mg/kg-day) - The Average Daily Dose (ADD) of the contaminant through water pathway indicates the quantity of chemical substance ingested per kilogram of body weight per day;

- $\mathrm{C}$ is Concentration of contaminant in the environmental media (e.g. $\mu \mathrm{g} / \mathrm{L}$, $\mathrm{mg} / \mathrm{L}$ );

- IR is Ingestion rate per unit time (e.g. $\mathrm{mg} /$ day or L/day);

- EF is Exposure frequency (day/year);

- ED is Exposure duration (years);

- BW is Body weight of receptor $(\mathrm{kg})$;

- $\mathrm{AT}$ is Averaging time $=$ life expectancy (years) 365 is the conversion factor from years to days;

- For non-carcinogenic effects, $\mathrm{AT}=\mathrm{ED}$ in days; carcinogenic effect, $\mathrm{AT}=70$ years or 25,550 days (Hu et al., 2012).

\subsection{Dose-Response/Toxicity Assessment}

This is the quantitative relationship that indicates the contaminants degree of toxicity to exposed species. It also involves the identification of the toxicity criteria used to evaluate human health risk associated with the chemical of concern in the study area. The amount of chemical that can affect human health is estimated. The Reference Dose RfD is used for non-carcinogen risk.

\subsection{Risk Characterization}

This is the final phase of the risk assessment process. In this phase, cumulative exposure and dose-response assessments are integrated to yield probabilities of effects occurring in human beings under specific exposure conditions and time scales. Also incorporated is information from hazard identification, exposure assessment, toxicity assessment and risk estimation to evaluate the potential risk to residents (USEPA, 2012).

\subsection{Carcinogenic Risk Assessment}

Carcinogenic risks were determined by calculating the potential of an individual to develop cancer as a result of cumulative exposure to each potential carcinogen over a lifetime, for carcinogen, identified by a weight-of-evidence classification of the chemical (Lushenko, 2010). The estimated daily dose and the cancer slope factor are multiplied together to find the lifetime cancer risk posed by the chemical. Cancer slope factors are estimates of carcinogenic potency and were used to relate estimated daily dose of the trace metal over a lifetime exposure to the lifetime probability of excess tumors Equation (2) (Lushenko, 2010; Koki et al., 2015; Kamunda et al., 2016). 


$$
\mathrm{CR}=\mathrm{ADD} \cdot \mathrm{SF}
$$

CR is the excess probability of developing cancer over a lifetime as a result of exposure to a contaminant or carcinogenic risk. It is unit less; SF is the slope factor of the contaminant $[\mathrm{mg} / \mathrm{kg} / \mathrm{d}]^{-1}$.

\subsection{Non Carcinogenic Risk Assessment}

Non-carcinogenic hazards are characterized by the hazard quotient (HQ). HQ is a unitless number that is expressed as the probability of an individual suffering an adverse effect. To estimate noncarcinogenic risk, the hazard quotient (HQ) was calculated using Equation (3) (Song et al., 2015).

$$
\mathrm{HQ}=\frac{\mathrm{ADD}}{\mathrm{RfD}}
$$

$\mathrm{RfD}$ is the reference dose $\mathrm{mg} / \mathrm{kg} / \mathrm{d}$. It represents a toxicity index of a daily exposure to the population in comparison to a safe level of exposure orally over a lifetime (Kim et al., 2011).

\subsection{Hazard Index (HI)}

It is the toxic risks due to all the potentially hazardous substances present in the same media simultaneously (Kolluru et al., 1996). Since more than one toxicant is evaluated, the interactions of all the toxicants were considered and assumed to be cumulative. Thus, the HI was calculated by summing all the HQ for all toxicants, Equation (4) (Song et al., 2015).

$$
\mathrm{HI}=\sum_{i=1}^{n} \mathrm{HQ}_{i}
$$

\subsection{Pollution Evaluation Indices}

Generally, pollution indices are estimated for a specific use of the water under consideration. The trace metal degree of contamination (DC), enrichment factor $(\mathrm{EF})$, ecological risk index $\left(E_{r}\right)$, potential ecological risk index (RI), pollution load index (PLI) and geo-accumulation index $\left(I_{\text {geo }}\right)$ were used to evaluate the pollution potential of the study area as in Table 3 .

Table 3. Formulae for calculation of pollution indices.

\begin{tabular}{ccc}
\hline Trace element pollution indices & Formulae & Reference \\
\hline $\begin{array}{c}\text { Degree of contamination } \\
\text { Enrichment factor }\end{array}$ & $\mathrm{DC}=\sum_{i=1}^{n} C_{f}^{i}$ & (Edet \& Offiong, 2002) \\
Ecological risk factor & ER $=\frac{(\mathrm{Ci} / \mathrm{Cie}) \text { sample }}{(\mathrm{Ci} / \mathrm{Cie}) \text { background }}$ & (Zhang et al., 2007) \\
Ecological risk index & $E_{r}^{i}=T_{r}^{i} \times C_{f}^{i}$ & Hakanson (1980) \\
pollution load index & $\mathrm{RI}_{i}=\sum_{i=1}^{n} E_{r}^{i}$ & Hakanson (1980) \\
Geo-accumulation index & $\mathrm{PLI}=\sqrt[n]{C_{f 1} \times C_{f 2} \times \cdots \times C_{f n}}$ & (Harikumar et al., 2009) \\
\hline
\end{tabular}




\section{Results and Discussion}

\section{Physicochemical Parameters}

The physicochemical parameters groundwater in the study area: temperature, $\mathrm{pH}, \mathrm{EC}$ and TDS were evaluated as shown in Table 4.

\subsection{Water Level Fluctuations}

Depth-to static water level (m) of groundwater ranged from: 0 - 0.77 as in Figure 3. Areas with low depths to static water levels are susceptible to pollution if the wells are not appropriately constructed and protected.

Table 4. Field determined physicochemical parameters; electrical conductivity (EC), pH, total dissolved solids (TDS) and temperature of groundwater in study area

\begin{tabular}{cccc}
\hline Parameter & Min & Max & Mean \\
\hline $\mathrm{T}\left({ }^{\circ} \mathrm{C}\right)$ & 26.2 & 30.6 & 28.3 \\
$\mathrm{PH}$ & 5.2 & 9.1 & 7.0 \\
$\mathrm{EC}(\mathrm{mS} / \mathrm{cm})$ & 1.2 & 1504 & 231.3 \\
$\mathrm{TDS}(\mathrm{mg} / \mathrm{L})$ & 0.8 & 1007.7 & 155.0 \\
\hline
\end{tabular}

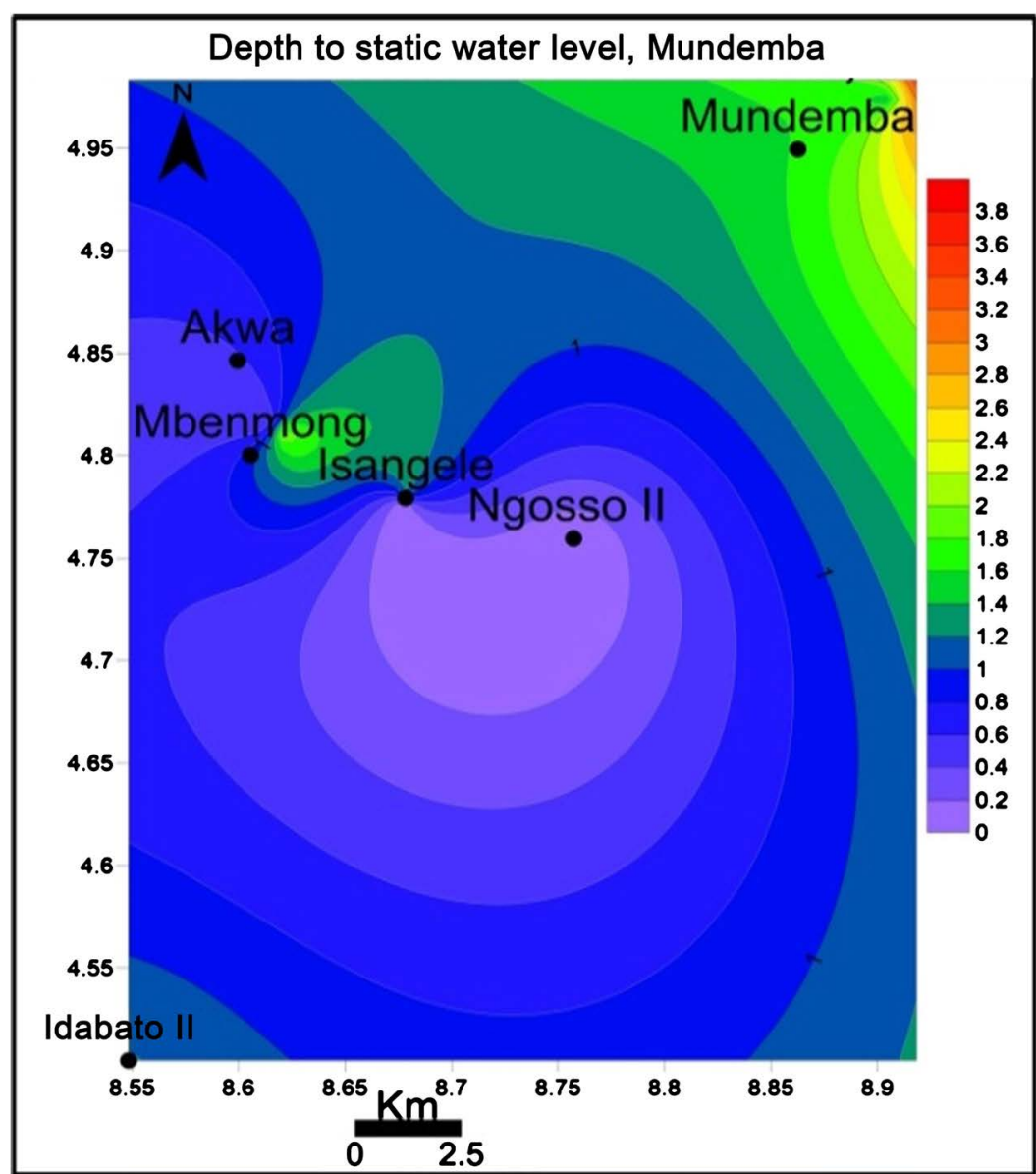

Figure 3. Depth to static water level; high values are at Mundemba whereas low values are at Ngosso II, Akwa, Idiabato II and Isangele. 


\subsection{Groundwater Flow Direction}

Groundwater flows towards the Northwestern part of the study area which could probably be a recharge zone as in Figure 4.

\subsection{Temperature}

Temperature values of groundwater ranged from: $26.2^{\circ} \mathrm{C}-30.6^{\circ} \mathrm{C}$ as seen in Figure 5. The temperature variation is similar in the different areas, suggesting a single aquifer since groundwater in the same aquifers have similar parameter values and temperature is one of them.

\section{4. $\mathrm{pH}$}

The $\mathrm{pH}$ value of most of the groundwater samples in the study area ranged from $5.2-9.1$ as in Figure 6. The value of $\mathrm{pH}$ of a water sample is recognized as an index of classifying groundwater as acidic $<5.5$, slightly acidic $5.5-6.5$, neutral $6.5-7.5$, slightly alkaline $7.5-8$, moderately alkaline $8-9$ and alkaline $>9$. This clearly shows that the groundwater in the study area is acidic to alkaline.

\subsection{Electrical Conductivity}

The EC ranged from $12-15,040 \mathrm{mS} / \mathrm{m}$ as in Figure 7. The high electrical

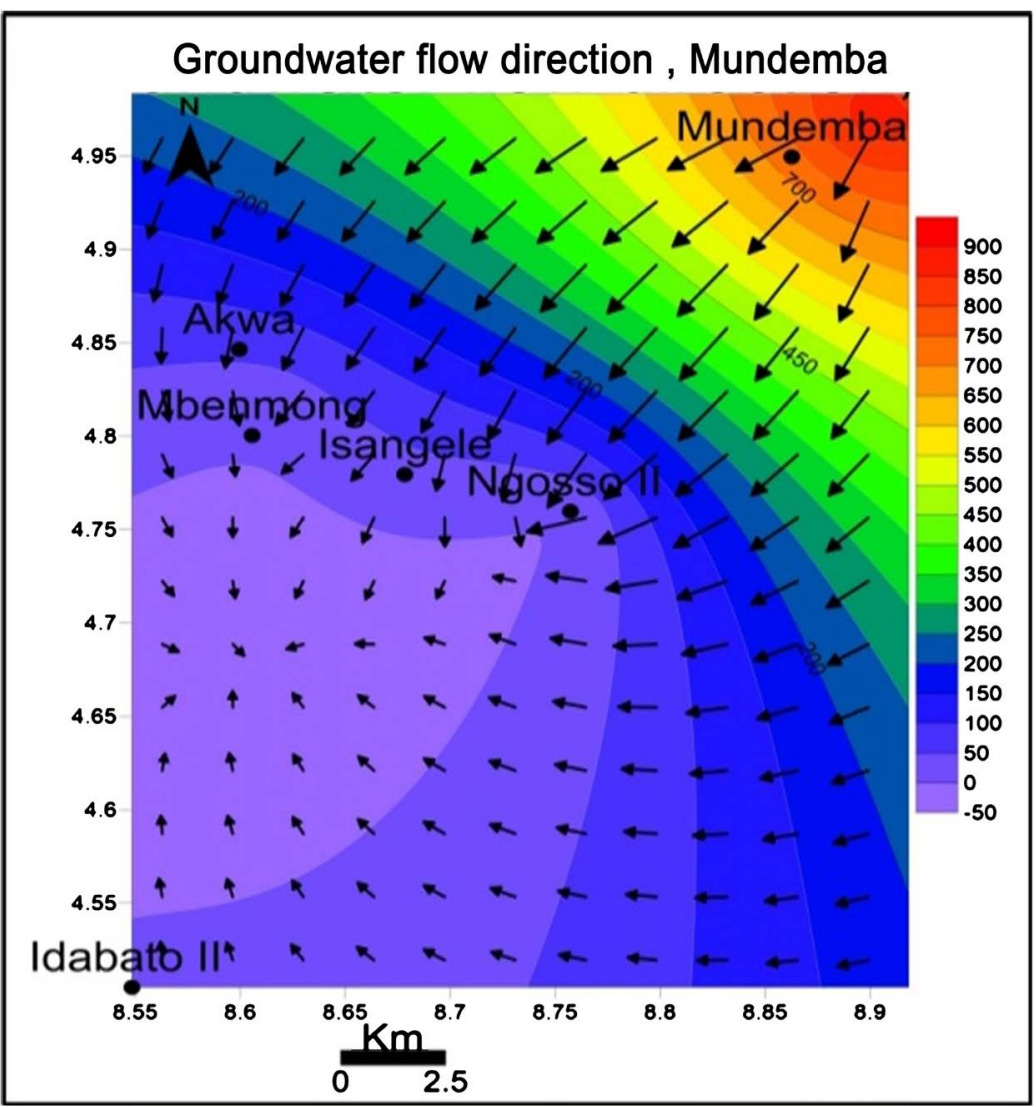

Figure 4. Groundwater flow direction in study area indicating that water flows towards the Southwestern part of the study area. 


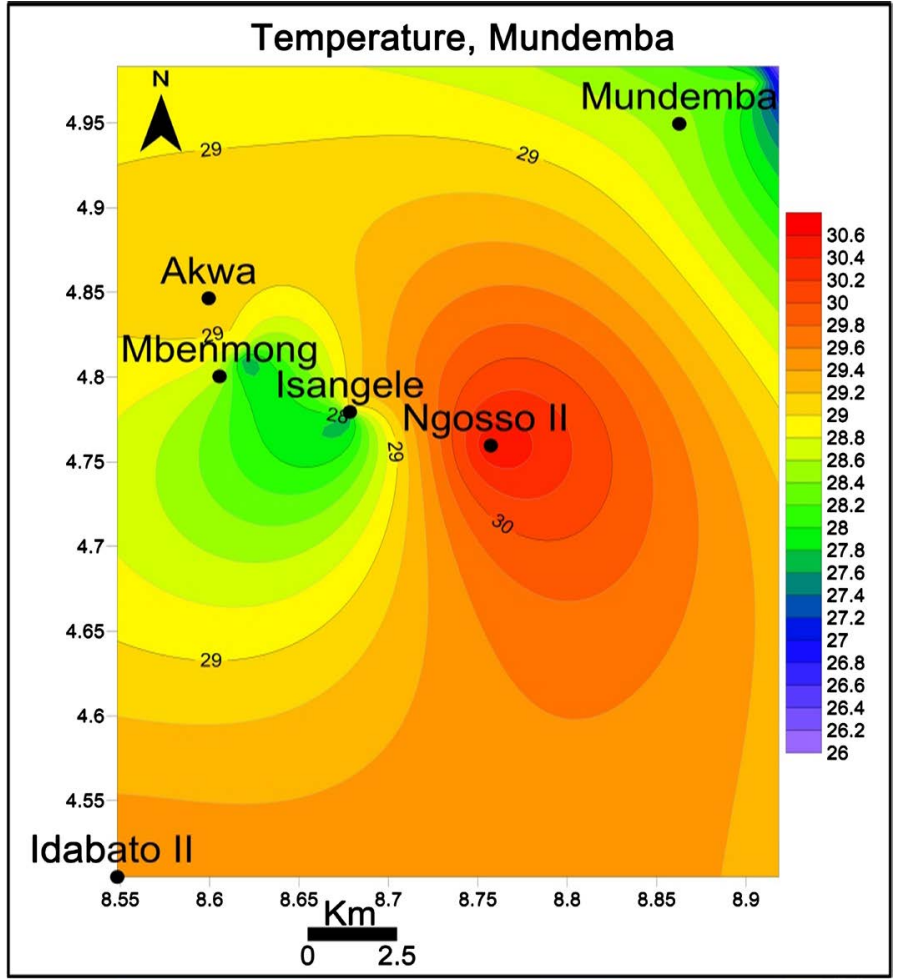

Figure 5. Spatial variation of groundwater temperatures; Temperatures are generally higher at Ngosso II and Idabato II while low values are at Isangele.

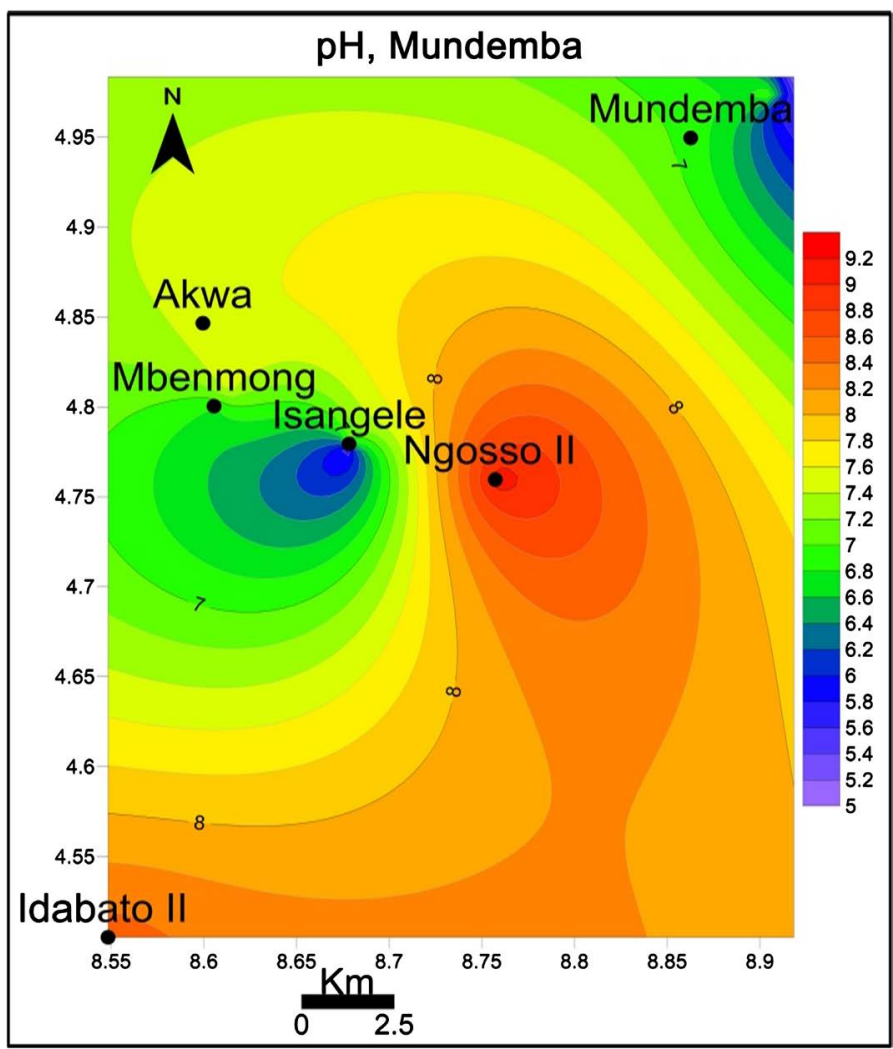

Figure 6. Spatial variation of $\mathrm{pH}$; High $\mathrm{pH}$ values are at Ngosso II and Idabato II while low values are at Isangele. 


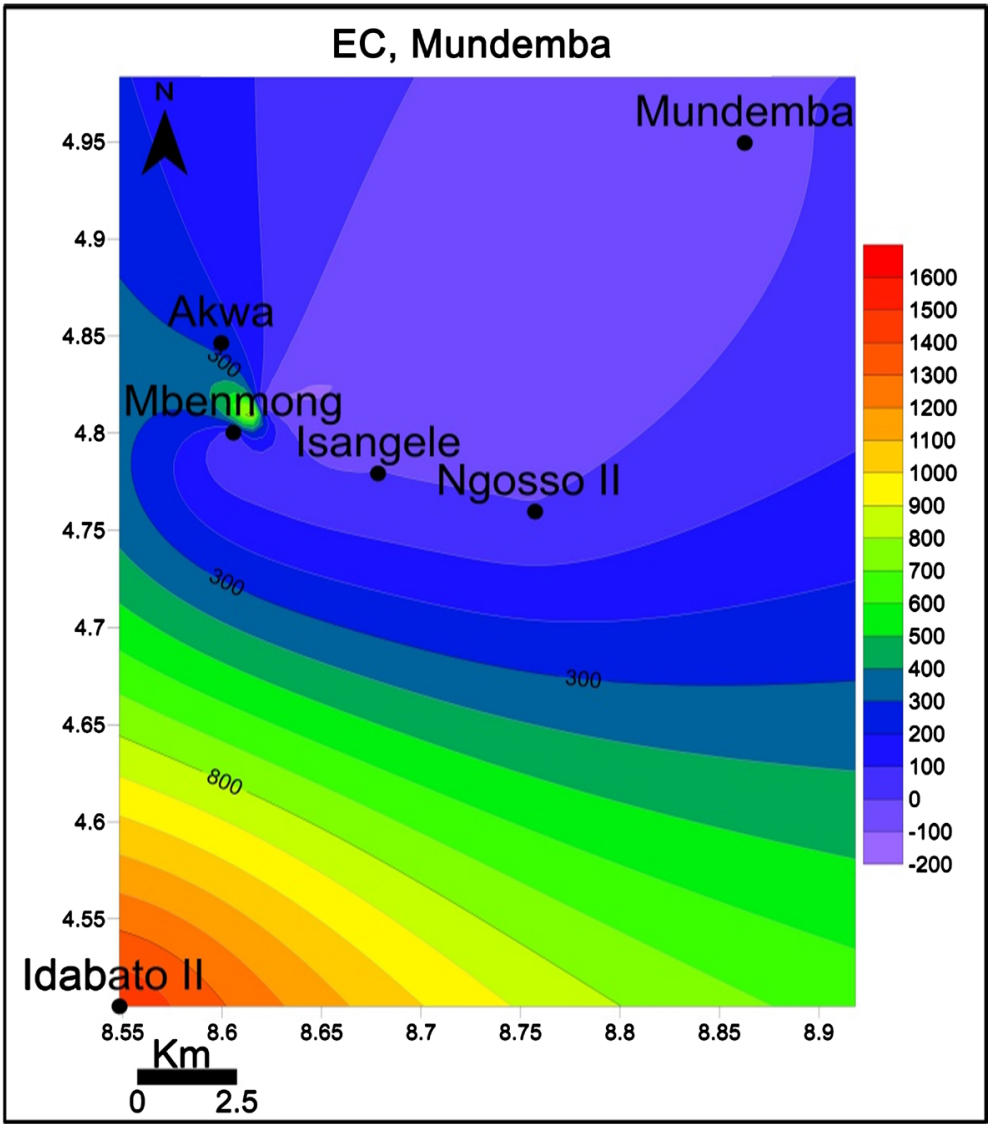

Figure 7. Spatial variation of Electrical Conductivities $(\mathrm{mS} / \mathrm{m})$; EC is at maximum at Idiabato II and minimum at Isangele and Mundemba.

conductivity is due to high solute concentration in groundwater. This high EC is characteristic of high saline waters with EC $>2250$, high concentration $\mathrm{Na}^{+}$, $\mathrm{HCO}_{3}$ and $\mathrm{CO}_{3}^{2-}$ ions characterized by high $\mathrm{pH}$.

\subsection{Total Dissolved Solids}

The total dissolved solids ranged from $0.80-1007.7 \mathrm{mg} / \mathrm{L}$ as in Figure 8. A TDS of 500-1500 indicates water is slightly saline.

\subsection{Summary of Trace Metal Concentration}

The results for twelve samples of trace metal analysis ICP-MS are presented in Table 5. The concentrations of fourteen trace metals; $\mathrm{Zn}, \mathrm{Pb}, \mathrm{Co}, \mathrm{Cu}, \mathrm{Cr}, \mathrm{Mn}, \mathrm{Sr}$, $\mathrm{Cd}, \mathrm{V}, \mathrm{Fe}, \mathrm{Ni}, \mathrm{As}, \mathrm{Li}, \mathrm{Ba}, \mathrm{Mn}$, and $\mathrm{Pb}$ were evaluated since they were of significance. All concentrations of these trace metals are below the WHO (2011) allowable limits except Fe which had concentration above permissible limits. However, the cumulative effects of long term consumption of these trace metals in the groundwater necessitated a health risk assessment.

Average concentrations of these trace metals were in the decreasing order as follows in $\mu \mathrm{g} / \mathrm{L}: \mathrm{Fe}$ (122631), $\mathrm{Zn}$ (334.2), $\mathrm{Sr}$ (88.9), $\mathrm{Mn}$ (47.84), $\mathrm{Cu}$ (19.21), Ba (18.6), Ni (5.18), Li (2.23), Pb (2.21), As (1.53), Co (1.5), Cr (0.56), V (0.32) and 


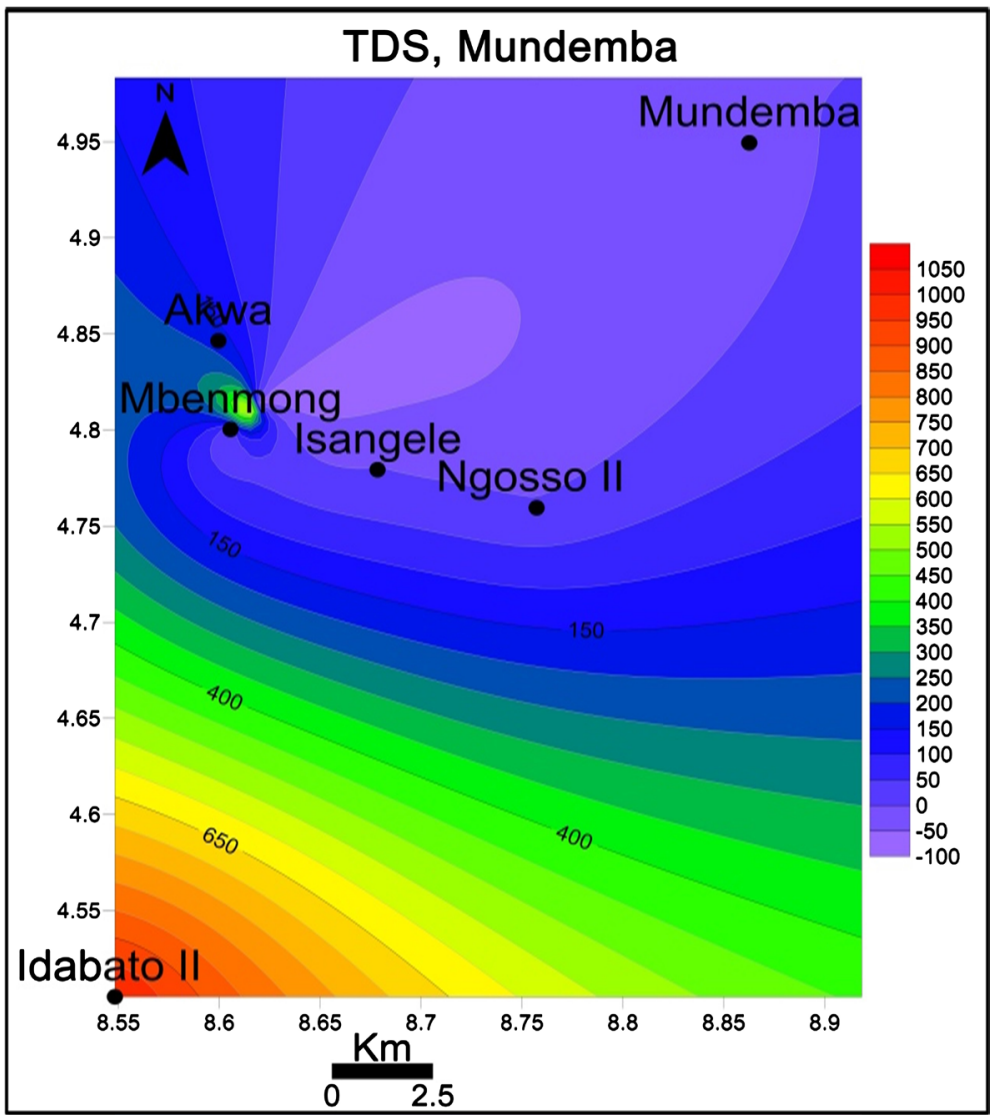

Figure 8. Spatial variation of total dissolved solids mg/L; TDS is at maximum at Idiabato II and minimum at Isangele and Mundemba.

Table 5. Trace metal concentration $(\mu \mathrm{g} / \mathrm{L})$ and basic statistics of groundwater in Akwa-Mundemba.

\begin{tabular}{|c|c|c|c|c|c|c|c|c|c|c|c|c|c|c|c|}
\hline SN & Location & $\mathrm{Li}$ & $\mathrm{V}$ & $\mathrm{Cr}$ & Mn & $\mathrm{Fe}$ & Co & $\mathrm{Ni}$ & $\mathrm{Cu}$ & $\mathrm{Zn}$ & As & $\mathrm{Sr}$ & $\mathrm{Cd}$ & $\mathrm{Ba}$ & $\mathrm{Pb}$ \\
\hline 1 & Idabato II & 12.11 & 0.60 & 0.30 & 53.38 & 99.22 & 4.12 & 0.32 & 98.54 & 5.47 & 17.04 & 754.41 & 0.01 & 27.29 & 0.22 \\
\hline 2 & Ngosso II & 0.64 & 0.61 & 0.87 & 47.75 & 229.76 & 0.55 & 2.47 & 6.30 & 20.29 & 0.36 & 24.57 & 0.10 & 1.77 & 0.96 \\
\hline 3 & Akwa-1 & 0.71 & 0.19 & 0.41 & 13.42 & 6516.33 & 0.54 & 2.45 & 4.77 & 23.00 & 0.19 & 11.13 & 0.06 & 6.29 & 1.30 \\
\hline 4 & Akwa-2 & 1.92 & 0.15 & 0.33 & 84.36 & 1245.06 & 1.06 & 2.73 & 10.39 & 470.37 & 0.08 & 76.84 & 0.08 & 91.30 & 2.68 \\
\hline 5 & Akwa-3 & 1.99 & 0.11 & 0.14 & 120.26 & 2136.29 & 2.14 & 0.69 & 1.65 & 7.72 & 0.15 & 102.91 & 0.02 & 13.95 & 0.81 \\
\hline 6 & Mbenmong & 2.00 & 0.07 & 0.24 & 9.73 & 155.13 & 0.24 & 0.77 & 40.96 & 41.04 & 0.01 & 6.89 & 0.03 & 7.35 & 3.14 \\
\hline 7 & Isangele-1 & 1.78 & 0.04 & 0.06 & 129.64 & 3654.56 & 1.81 & 10.41 & 10.90 & 3008.02 & 0.03 & 8.51 & 0.04 & 6.51 & 0.32 \\
\hline 8 & Isangele-2 & 0.80 & 0.17 & 0.57 & 16.59 & 190.52 & 0.62 & 2.18 & 3.53 & 54.09 & 0.11 & 7.00 & 0.07 & 20.97 & 1.02 \\
\hline 9 & Mundemba-1 & 1.32 & 0.60 & 1.43 & 20.19 & 165.82 & 1.78 & 13.19 & 17.63 & 123.22 & 0.09 & 16.61 & 0.97 & 17.34 & 4.31 \\
\hline 10 & Mundemba-2 & 1.83 & 0.53 & 1.04 & 16.67 & 137.48 & 1.49 & 10.06 & 15.10 & 89.14 & 0.09 & 13.99 & 0.34 & 10.17 & 4.30 \\
\hline 11 & Mundemba-3 & 0.18 & 0.38 & 0.67 & 41.26 & 93.06 & 2.08 & 9.81 & 10.62 & 68.02 & 0.09 & 26.84 & 0.27 & 9.09 & 3.81 \\
\hline \multirow[t]{5}{*}{12} & Mundemba-4 & 1.48 & 0.40 & 0.58 & 20.89 & 92.53 & 1.54 & 7.13 & 10.15 & 100.00 & 0.09 & 17.06 & 0.45 & 11.16 & 3.66 \\
\hline & Min & 0.18 & 0.04 & 0.06 & 9.73 & 92.53 & 0.24 & 0.32 & 1.65 & 5.47 & 0.01 & 6.89 & 0.01 & 1.77 & 0.22 \\
\hline & $\operatorname{Max}$ & 12.11 & 0.61 & 1.43 & 129.64 & 6516.33 & 4.12 & 13.19 & 98.54 & 3008.02 & 17.04 & 754.41 & 0.97 & 91.30 & 4.31 \\
\hline & Mean & 2.23 & 0.32 & 0.56 & 47.84 & 1226.31 & 1.50 & 5.18 & 19.21 & 334.20 & 1.53 & 88.90 & 0.20 & 18.60 & 2.21 \\
\hline & VHO limit & 200 & 200 & 50 & 400 & 2000 & 10 & 70 & 2000 & 5000 & 10 & 400 & 3 & 70 & 10 \\
\hline
\end{tabular}


$\mathrm{Cd}(0.2)$. The trace metal with the highest concentration is Fe with a maximum value of $651,633 \mu \mathrm{g} / \mathrm{L}$ detected at Akwa.

\subsection{Pearson's Correlation Analysis PCA between Trace Metals and Physico-Chemical Parameters}

Correlation between trace metals in groundwater within the study area was carried out using Pearson's correlation analysis (PCA) as shown in Table 6 to establish the relationships that exist between the variables; trace metals and the physico-chemical parameters as in Table 2 . $\mathrm{r}$ values $>0.5$ or $<-0.5$ are significant, 0.72 strong (moderate) and 0.80 Very strong correlation.

Positive values indicate a positive relationship while negative values of $r$ indicate an inverse relationship. A very strong positive correlation exists between the following trace metals; $\mathrm{Li}$ and $\mathrm{Cu}, \mathrm{As}$ and $\mathrm{Li}, \mathrm{Sr}$ and $\mathrm{Li}, \mathrm{Sr}$ and $\mathrm{Co}, \mathrm{As}$ and $\mathrm{Cu}, \mathrm{Sr}$ and $\mathrm{Cu}, \mathrm{Sr}$ and $\mathrm{As}, \mathrm{Cd}$ and $\mathrm{Cr}, \mathrm{PH}$ and temperature, TDS and EC. A strong positive correlation exists between the following; Co and $\mathrm{Li}, \mathrm{EC}$ and $\mathrm{Li}$, TDS and $\mathrm{Li}$, $\mathrm{Cr}$ and $\mathrm{V}$, As and $\mathrm{Co}, \mathrm{Cd}$ and $\mathrm{Ni}, \mathrm{As}$ and EC. A negative correlation exists between the following; $\mathrm{V}$ and $\mathrm{Mn}, \mathrm{Mn}$ and $\mathrm{Cr}, \mathrm{Zn}$ and $\mathrm{Cr}, \mathrm{Cd}$ and $\mathrm{Mn}$, TDS and Ni.

\subsection{Hierarchical Cluster Analysis HCA}

The R-mode cluster analysis; hierarchical cluster analysis HCA, performed on

Table 6. Correlation matrix of $r$ values for trace metals and physico-chemical parameters in Akwa-Mundemba.

\begin{tabular}{|c|c|c|c|c|c|c|c|c|c|c|c|c|c|c|c|c|c|c|}
\hline & $\mathrm{Li}$ & $\mathrm{V}$ & $\mathrm{Cr}$ & Mn & $\mathrm{Fe}$ & Co & $\mathrm{Ni}$ & $\mathrm{Cu}$ & $\mathrm{Zn}$ & As & $\mathrm{Sr}$ & $\mathrm{Cd}$ & $\mathrm{Ba}$ & $\mathrm{Pb}$ & Temp & $\mathrm{pH}$ & EC & TDS \\
\hline $\mathrm{Li}$ & 1 & & & & & & & & & & & & & & & & & \\
\hline $\mathrm{V}$ & 0.32 & 1 & & & & & & & & & & & & & & & & \\
\hline $\mathrm{Cr}$ & -0.26 & 0.75 & 1 & & & & & & & & & & & & & & & \\
\hline Mn & 0.11 & -0.39 & -0.56 & 1 & & & & & & & & & & & & & & \\
\hline $\mathrm{Fe}$ & -0.18 & -0.49 & -0.42 & 0.27 & 1 & & & & & & & & & & & & & \\
\hline Co & 0.78 & 0.39 & -0.10 & 0.34 & -0.19 & 1 & & & & & & & & & & & & \\
\hline $\mathrm{Ni}$ & -0.34 & 0.29 & 0.59 & -0.05 & -0.11 & 0.10 & 1 & & & & & & & & & & & \\
\hline $\mathrm{Cu}$ & 0.94 & 0.34 & -0.17 & -0.10 & -0.29 & 0.66 & -0.29 & 1 & & & & & & & & & & \\
\hline $\mathrm{Zn}$ & -0.07 & -0.42 & -0.38 & 0.64 & 0.37 & 0.07 & 0.37 & -0.12 & 1 & & & & & & & & & \\
\hline As & 0.98 & 0.40 & -0.19 & 0.04 & -0.18 & 0.78 & -0.34 & 0.92 & -0.13 & 1 & & & & & & & & \\
\hline $\mathrm{Sr}$ & 0.98 & 0.36 & -0.24 & 0.13 & -0.17 & 0.81 & -0.38 & 0.89 & -0.14 & 0.99 & 1 & & & & & & & \\
\hline $\mathrm{Cd}$ & -0.23 & 0.54 & 0.83 & -0.38 & -0.32 & 0.07 & 0.75 & -0.15 & -0.17 & -0.22 & -0.25 & 1 & & & & & & \\
\hline $\mathrm{Ba}$ & 0.17 & -0.16 & -0.16 & 0.25 & -0.10 & 0.06 & -0.21 & 0.07 & -0.02 & 0.11 & 0.19 & -0.10 & 1 & & & & & \\
\hline $\mathrm{Pb}$ & -0.38 & 0.29 & 0.63 & -0.53 & -0.43 & -0.19 & 0.59 & -0.20 & -0.33 & -0.40 & -0.41 & 0.72 & 0.05 & 1 & & & & \\
\hline Temp & 0.35 & 0.11 & -0.36 & 0.28 & 0.08 & 0.11 & -0.46 & 0.30 & 0.15 & 0.36 & 0.35 & -0.64 & -0.35 & -0.64 & 1 & & & \\
\hline $\mathrm{pH}$ & 0.41 & 0.15 & -0.33 & 0.32 & 0.22 & 0.15 & -0.56 & 0.32 & -0.02 & 0.43 & 0.45 & -0.62 & 0.02 & -0.58 & 0.86 & 1 & & \\
\hline EC & 0.71 & 0.19 & -0.24 & -0.13 & 0.40 & 0.46 & -0.40 & 0.65 & -0.17 & 0.76 & 0.74 & -0.29 & 0.00 & -0.44 & 0.28 & 0.46 & 1 & \\
\hline TDS & 0.71 & 0.19 & -0.24 & -0.13 & 0.40 & 0.46 & -0.40 & 0.65 & -0.17 & 0.76 & 0.74 & -0.29 & 0.00 & -0.44 & 0.27 & 0.46 & 1.0 & 1 \\
\hline
\end{tabular}


the groundwater of the Akwa-Mundemba area shows two clusters based on spatial similarities and dissimilarities as shown in Figure 9. The trace metals fall in two clusters: Cluster one (1) Fe, soluble. Cluster (2), slightly soluble, is divided into two classes; class (1) Zn, immobile. Class (2) further divided into two subclasses; subclass (1) Sr, slightly mobile. Subclass two V, Cd, Cr, Co, Pb, Li, As, $\mathrm{Ni}, \mathrm{Cu}, \mathrm{Ba}$ and $\mathrm{Mn}$; mobile under present $\mathrm{EC}, \mathrm{pH}$ and temperature conditions which is indicative that they originate from different parent rocks.

\section{Health Risk Assessment}

Human health risk assessment was done to estimate the intensity, frequency, and duration of human exposures to environmental contaminants using the parameters in Table 7. Exposure assessment was carried out by measuring the average daily dose ADD of the trace metals selected in Table 5. Carcinogenic and non carcinogenic risk was calculated from the ADD.

\subsection{Average Daily Dose}

ADD values ranged as follows; (Li) $5.59 \times 10^{-6}$ to $3.8 \times 10^{-4}$, (V) $1.12 \times 10^{-6}$ to $1.9 \times 10^{-5}$, (Cr) $1.86 \times 10^{-6}$ to $4.49 \times 10^{-5}$, (Mn) $3.1 \times 10^{-4}$ to $4 \times 10^{-3}$, (Fe) $2.9 \times$ $10^{-3}$ to 0.2 , (Co) $7.6 \times 10^{-6}$ to $1.3 \times 10^{-4}$, (Ni) $1 \times 10^{-5}$ to $4.4 \times 10^{-4}$, (Cu) $5.2 \times$ $10^{-5}$ to $3.1 \times 10^{-3},(\mathrm{Zn}) 1.7 \times 10^{-4}$ to $9.4 \times 10^{-2}$, (As) $4.6 \times 10^{-7}$ to $5.4 \times 10^{-4}$, ( $\left.\mathrm{Sr}\right)$ $2.2 \times 10^{-4}$ to $2.3 \times 10^{-2}$, (Cd) $2.7 \times 10^{-7}$ to $3.1 \times 10^{-5}$, (Ba) $5.6 \times 10^{-5}$ to $2.6 \times 10^{-3}$, $(\mathrm{Pb}) 6.8 \times 10^{-6}$ to $1.3 \times 10^{-4}$ as in Figure 10 .

\subsection{Hazard Qotient}

HQ values ranged as follow; $5.6 \times 10^{-4}$ to $9.5 \times 10^{-3}(\mathrm{~V}), 1.2 \times 10^{-3}$ to $7.7 \times 10^{-2}$ $(\mathrm{Cu}), 1.9 \times 10^{-3}$ to $3.8 \times 10^{-2}(\mathrm{~Pb}), 5.7 \times 10^{-4}$ to $3.1 \times 10^{-1}(\mathrm{Zn}), 4.1 \times 10^{-3}$ to $2.9 \times$ $10^{-1}(\mathrm{Fe}), 2.1 \times 10^{-2}$ to $2.9 \times 10^{-1}(\mathrm{Mn})$ as in Figure 11 .

\subsection{Carcinogenic Risk}

$\mathrm{CR}$ for the carcinogenic elements; $\mathrm{Pb}, \mathrm{Cr}, \mathrm{Cd}, \mathrm{Ni}$ and As are; $9.4 \times 10^{-6}$ to $1.1 \times$ $10^{-2}$ (As), $2.1 \times 10^{-6}$ to $2.5 \times 10^{-4}(\mathrm{Cd}), 1.0 \times 10^{-4}$ to $2.5 \times 10^{-4}(\mathrm{Cr}), 1.2 \times 10^{-5}$ to $4.9 \times 10^{-4}(\mathrm{Ni})$ as in Figure 12 .

Table 7. Parameters used for estimating exposure assessment (Lushenko, 2010).

\begin{tabular}{cccc}
\hline Factor/parameter & Symbol & Units & Residential \\
\hline Exposure duration & ED & Years & 30 \\
Exposure frequency & EF & Days in year & 350 \\
Average time & AT & Years & 76.5 \\
Body weight & BW & Kg & 70 \\
Ingestion rate & IR & L/day & 2.2 \\
Contaminant concentration & C & ug/L & Table 5
\end{tabular}




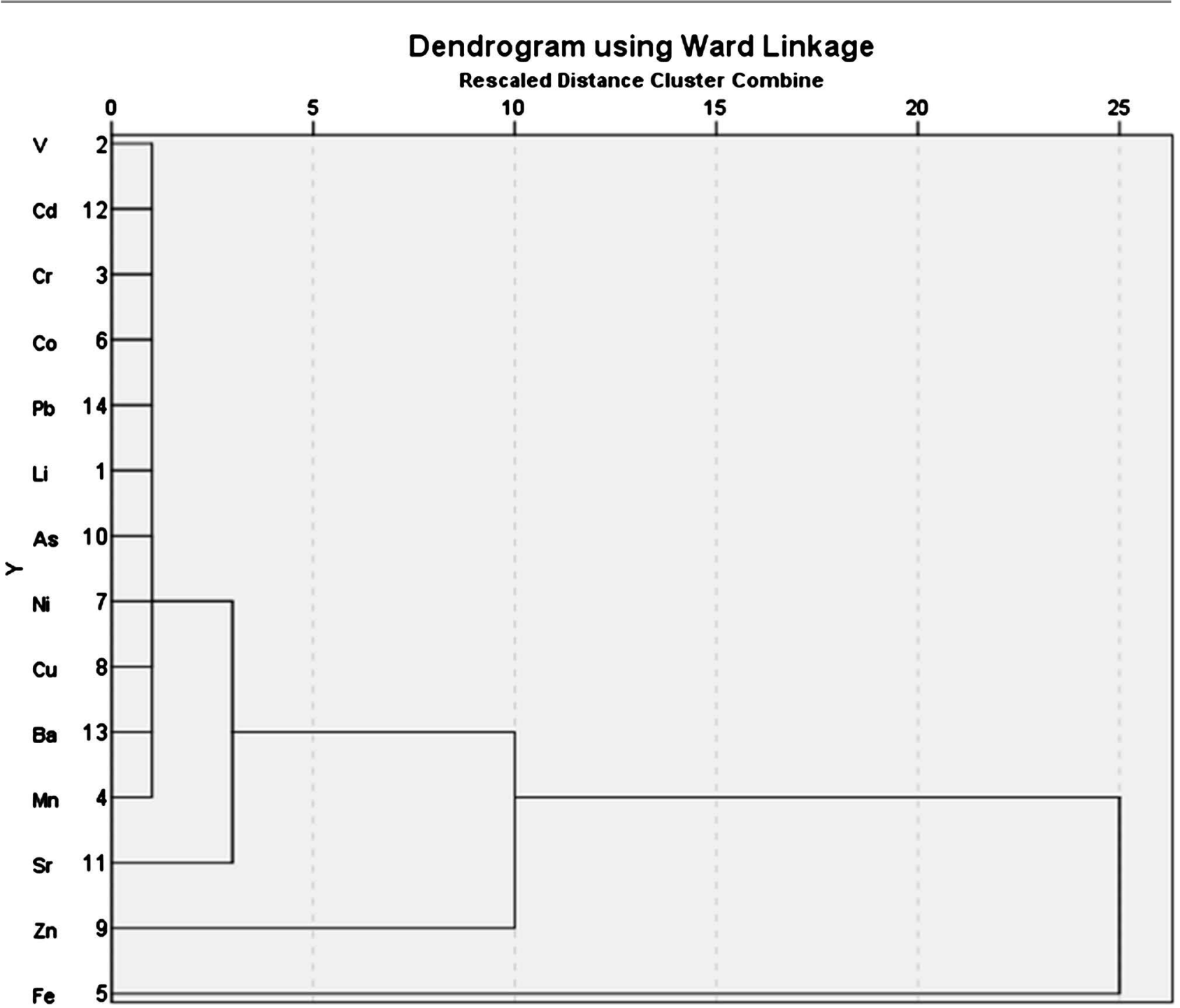

Figure 9. Dendrogram of trace metals in groundwater of the Akwa-Mundemba area made up of two clusters: Cluster one (1) Fe, soluble. Cluster (2), slightly soluble is divided into two classes; class (1) Zn, immobile. Class (2) further divided into two subclasses; subclass (1) Sr, slightly mobile. Subclass two V, Cd, Cr, Co, Pb, Li, As, Ni, Cu, Ba and Mn; mobile under present EC, pH and temperature conditions: Probably from different parent rocks.

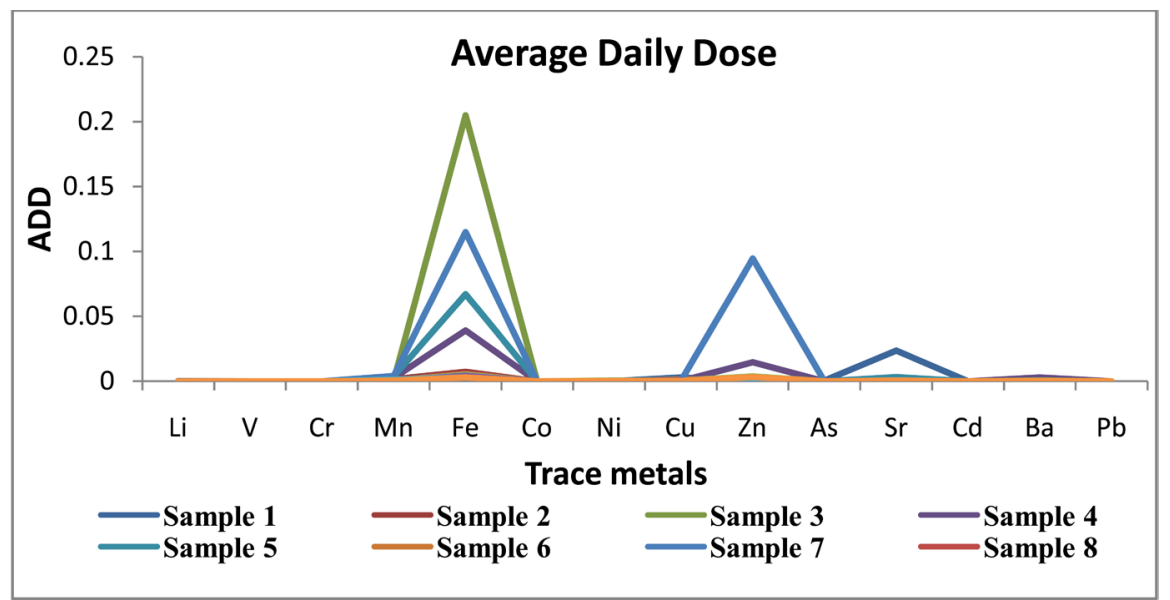

Figure 10. Average daily dose (ADD) of trace metals through water intake. All values are below toxic level. 


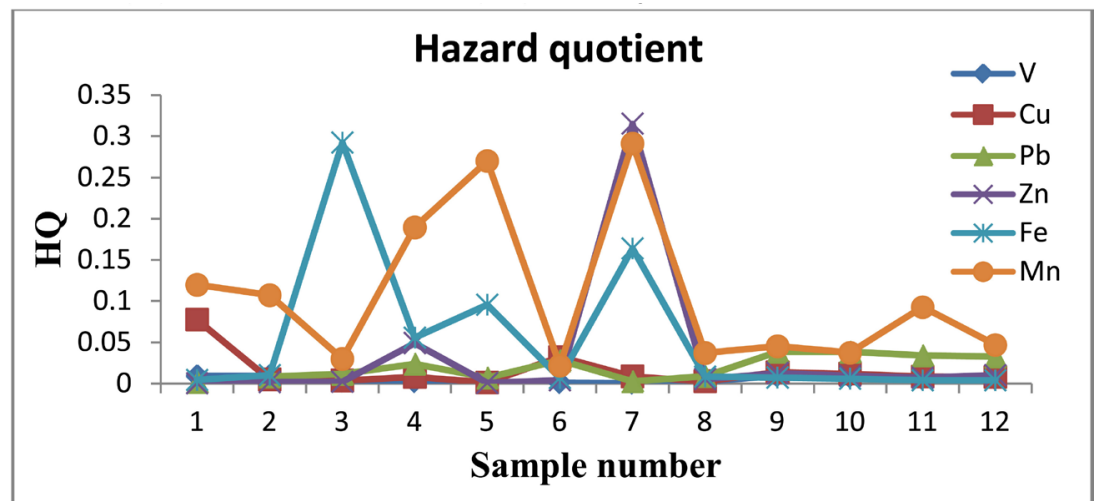

Figure 11. Hazard quotient (HQ) of trace metals through water intake. The values of Iron in sample 3, Manganese in sample 5, and Vanadiumx \& Copper in sample 7 are relatively high but all values are below toxic levels.

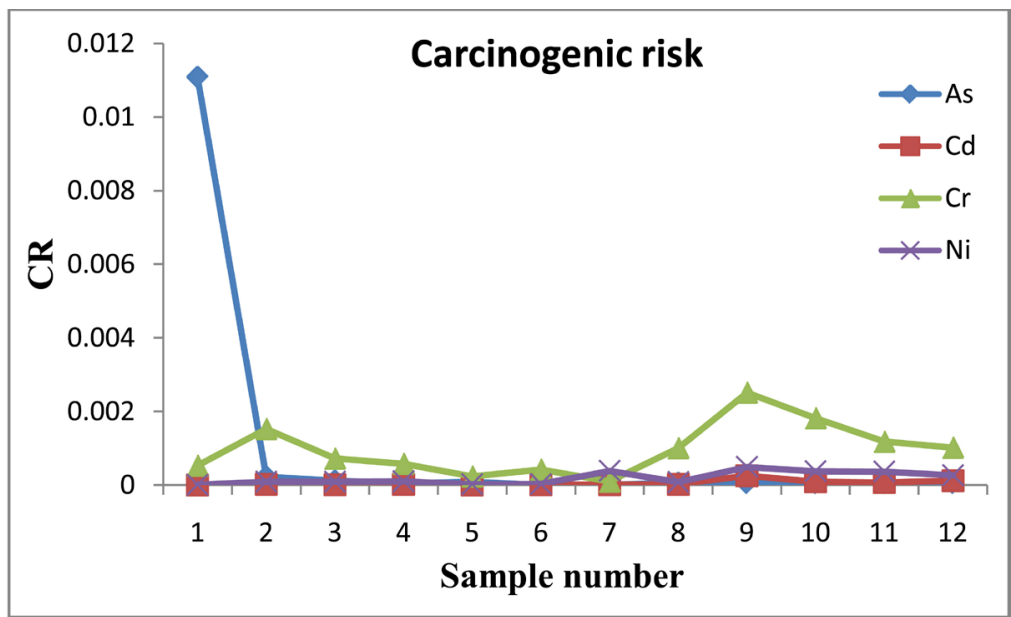

Figure 12. Carcinogenic risk (CR) of each contaminant. The values in sample 1 (Idabato II) is relatively high. All values are below toxic levels.

\subsection{Hazard Index}

$\mathrm{HI}$ is the cumulative sum of HQ. The values ranged between 0.06 and 0.78 for each of contaminant indicating no toxicity as in Figure 13.

All the groundwater risk indices; $\mathrm{ADD}, \mathrm{CR}, \mathrm{HQ}$ and $\mathrm{HI}$ were less than 1 in categories of insignificant health risk as shown in Table 8.

\section{Pollution Evaluation Indices}

\subsection{Degree of Contamination (DC)}

The degree of contamination (DC) is used as reference of estimating the extent of metal pollution. The DC values in the groundwater ranged from -13.5 to -11 as shown in Figure 14. According to the classification of Edet and Offiong (2002), $100 \%$ of the samples have low degree of contamination factors.

\subsection{Enrichment Factor}

Iron $(\mathrm{Fe})$ was chosen as a stationary reference element to perform this calcula- 
tion (Agunbiade et al., 2009). EF values $<2$ indicate that the metal is entirely from crustal materials or natural processes; whereas EF values $>2$ reveal that the sources are more likely to be anthropogenic (Liaghati et al., 2003). The enrichment factors of heavy metals in Mundemba were as shown in Figure 15 and Table 9. The sequence of $\mathrm{EF}$ in the sediments was $\mathrm{As}>\mathrm{Pb}>\mathrm{Ba}>\mathrm{Zn}>\mathrm{Co}>\mathrm{Cd}>\mathrm{Ni}>$ $\mathrm{Mn}>\mathrm{Sr}>\mathrm{Zn}>\mathrm{Li}>\mathrm{Cu}>\mathrm{Cr}>\mathrm{V}$. EF values in the study area are between 0.26 to 35.47 which is indicative of significant enrichment and that the source of these metals is from natural and anthropogenic processes. Arsenic is the most enriched element in the study area; this could be attributed to agricultural wastes.

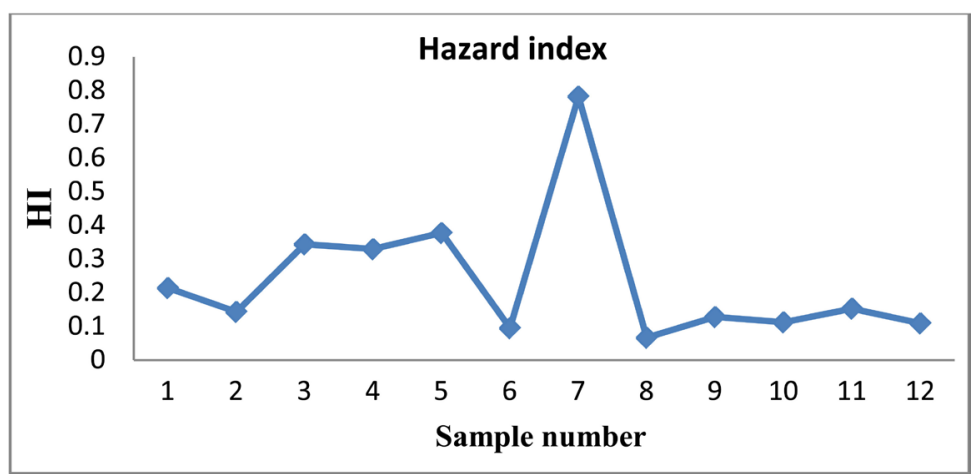

Figure 13. Non carcinogenic toxic risk index or hazard index (HI) of trace metals through water intake. The values in sample 7 (Isangele) is relatively high. All values are below toxic levels.

Table 8. Summary classification of health risk assessment carcinogenic and non-carcinogenic risk in Akwa-Mundemba.

\begin{tabular}{ccccc}
\hline Index & \multicolumn{1}{c}{ Range } & Classification & Samples & $(\%)$ \\
\hline CR & $\begin{array}{c}\text { greater than } 10 \mathrm{E}-6 \\
\text { and less than } 10 \mathrm{E}-4\end{array}$ & Generally satisfactory & 10 & 83.3 \\
& $>10^{-4}$ & Intolerable & 2 & 16.7 \\
$\mathrm{HQ}$ & $<1$ & Acceptable level (no concern) & 12 & 100 \\
$\mathrm{HI}$ & $<1$ & No carcinogenic adverse effects & - & - \\
& $>1$ & Safe & 12 & 100 \\
\end{tabular}

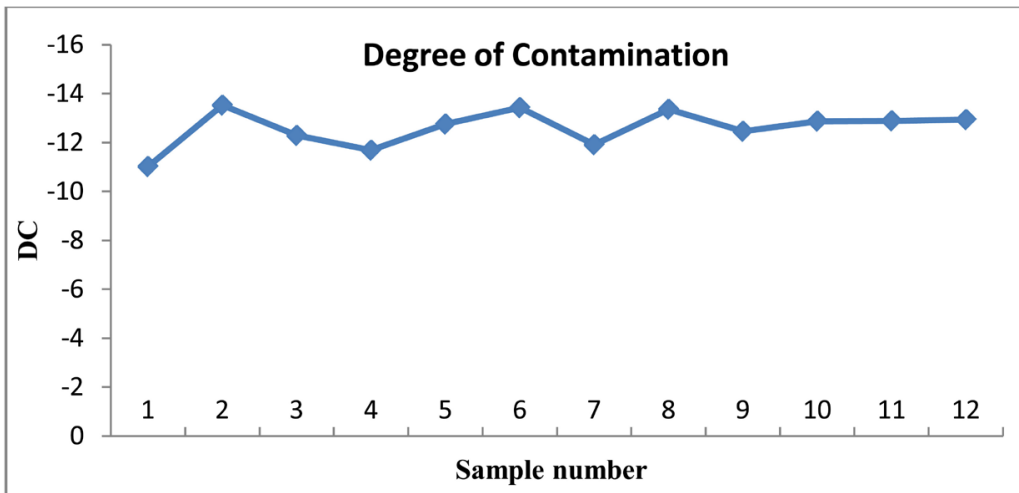

Figure 14. The degree of contamination for trace metals of groundwater in Mudemba. 


\subsection{Ecological Risk Assessment}

\subsubsection{Ecological Risk Factor (Er) and Ecological Risk Index (RI)}

Er and RI of the heavy metals in the investigated area are given in Table 9 and Figure 16 and Figure 17. All analyzed trace metals showed low potential ecological risk, it varied from -29.92 to $-0.39(\mathrm{Er}<40)$. RI of the studied trace metals

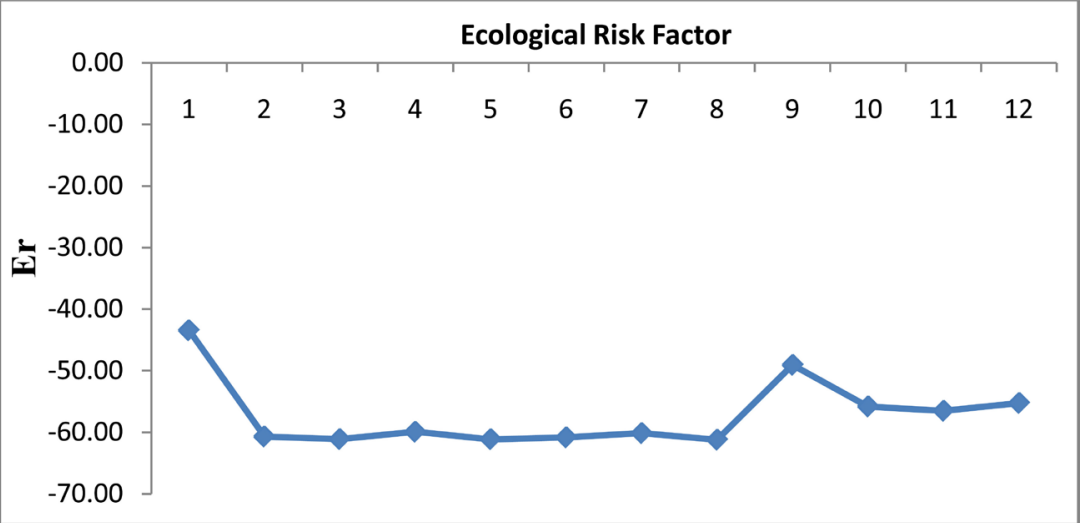

Figure 15. The enrichment factor for trace metal of groundwater in Mudemba. Cobalt, Arsenic and Lead are being enriched.

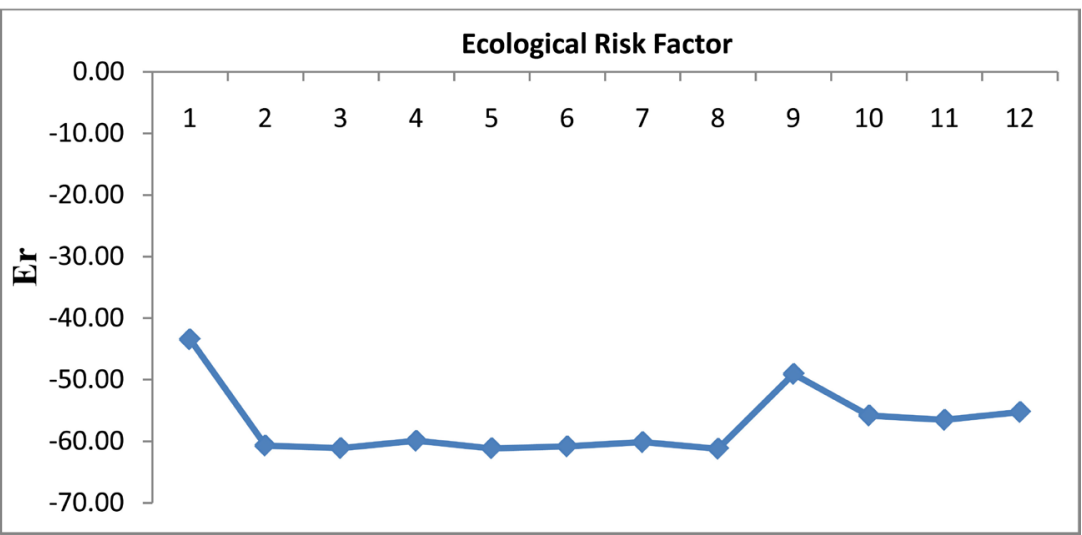

Figure 16. The ecological risk factor Er for trace metal of groundwater in Mudemba.

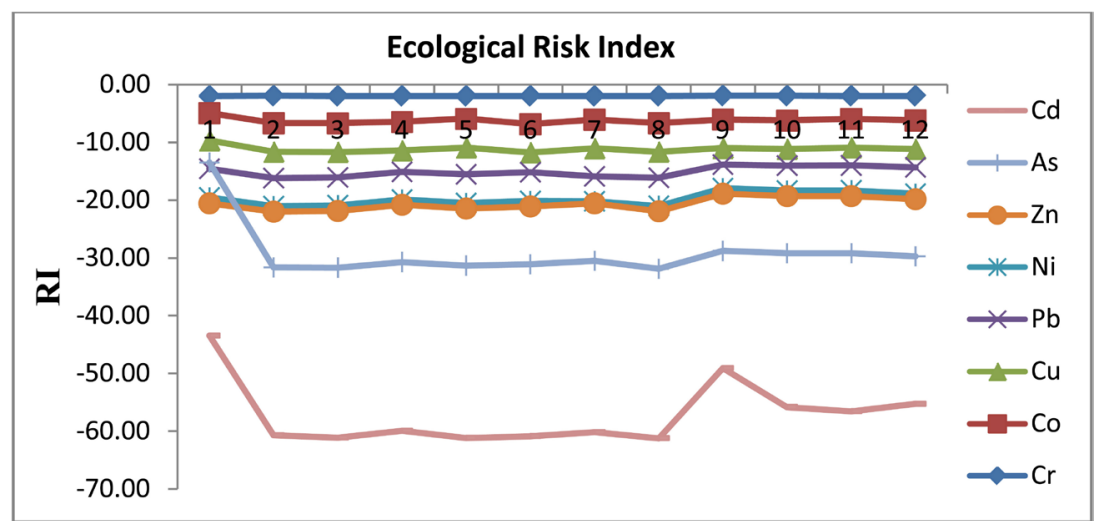

Figure 17. The ecological risk index for trace metalof groundwater in Mudemba. 
Table 9. The Geo-accumulation index (Igeo) of Mundemba groundwater.

\begin{tabular}{|c|c|c|c|c|c|c|c|c|c|c|c|c|c|c|}
\hline SN & $\mathrm{Li}$ & V & $\mathrm{Cr}$ & Mn & $\mathrm{Fe}$ & Co & $\mathrm{Ni}$ & $\mathrm{Cu}$ & $\mathrm{Zn}$ & As & $\mathrm{Sr}$ & $\mathrm{Cd}$ & $\mathrm{Ba}$ & $\mathrm{Pb}$ \\
\hline 1 & $4.8 \mathrm{E}-4$ & $2.3 \mathrm{E}-05$ & $3 E-06$ & $5.3 \mathrm{E}-3$ & $3.9 \mathrm{E}-2$ & $8.2 \mathrm{E}-06$ & $4.5 \mathrm{E}-05$ & $3.9 \mathrm{E}-2$ & $5.4 \mathrm{E}-3$ & $3.4 \mathrm{E}-05$ & 0.6 & $4.8 \mathrm{E}-09$ & $4 \mathrm{E}-4$ & 3.E-06 \\
\hline 3 & $2.8 \mathrm{E}-05$ & $7.6 \mathrm{E}-06$ & $4 \mathrm{E}-06$ & $1.3 \mathrm{E}-3$ & 2.6 & 1.E-06 & $3.4 \mathrm{E}-4$ & $1.9 \mathrm{E}-3$ & 0.02 & $3.8 \mathrm{E}-07$ & 0.01 & $3.5 \mathrm{E}-08$ & $9 E-05$ & $1.8 \mathrm{E}-05$ \\
\hline 4 & $7.7 \mathrm{E}-05$ & $5.8 \mathrm{E}-06$ & $3 E-06$ & $8.4 \mathrm{E}-3$ & 0.4 & $2.1 \mathrm{E}-06$ & $3.8 \mathrm{E}-4$ & $4.2 \mathrm{E}-3$ & 0.4 & $1.6 \mathrm{E}-07$ & 0.06 & $4.9 \mathrm{E}-08$ & $1.3 \mathrm{E}-3$ & $3.7 \mathrm{E}-05$ \\
\hline 5 & $8 \mathrm{E}-05$ & $4.2 \mathrm{E}-06$ & $1 \mathrm{E}-06$ & $1.2 \mathrm{E}-2$ & 0.8 & $4.2 \mathrm{E}-06$ & $9.7 \mathrm{E}-05$ & $7 \mathrm{E}-4$ & $7.7 \mathrm{E}-3$ & $2.9 \mathrm{E}-07$ & 0.08 & $1.1 \mathrm{E}-08$ & $2 \mathrm{E}-4$ & $1.1 \mathrm{E}-05$ \\
\hline 6 & $8 \mathrm{E}-05$ & $2.8 \mathrm{E}-06$ & $2 \mathrm{E}-06$ & $1 \mathrm{E}-2$ & $6.2 \mathrm{E}-2$ & $4.8 \mathrm{E}-07$ & $1.1 \mathrm{E}-4$ & $1.6 \mathrm{E}-2$ & 0.04 & $2.9 \mathrm{E}-08$ & 0.01 & $1.8 \mathrm{E}-08$ & $1 \mathrm{E}-4$ & $4.4 \mathrm{E}-05$ \\
\hline 7 & $7.1 \mathrm{E}-05$ & $1.4 \mathrm{E}-06$ & $6 \mathrm{E}-07$ & $1.3 \mathrm{E}-2$ & 1.4 & $3.6 \mathrm{E}-06$ & $1.46 \mathrm{E}-2$ & $4.4 \mathrm{E}-3$ & 3.0 & $6.7 \mathrm{E}-08$ & 0.01 & $2.4 \mathrm{E}-08$ & $9 \mathrm{E}-05$ & $4.4 \mathrm{E}-06$ \\
\hline 8 & $3.2 \mathrm{E}-05$ & $6.6 \mathrm{E}-06$ & $6 \mathrm{E}-06$ & $1.7 \mathrm{E}-3$ & $7.6 \mathrm{E}-2$ & $1.2 \mathrm{E}-06$ & $3.1 \mathrm{E}-4$ & $1.4 \mathrm{E}-3$ & 0.05 & $2.1 \mathrm{E}-07$ & 0.01 & $4 \mathrm{E}-08$ & $3 E-4$ & $1.4 \mathrm{E}-05$ \\
\hline 10 & $7.3 \mathrm{E}-05$ & $2.1 \mathrm{E}-05$ & $1 \mathrm{E}-05$ & $1.7 \mathrm{E}-3$ & $5.5 \mathrm{E}-2$ & $2.9 \mathrm{E}-06$ & $1.4 \mathrm{E}-3$ & $6 \mathrm{E}-3$ & 0.08 & $1.8 \mathrm{E}-07$ & 0.01 & $2 \mathrm{E}-07$ & $1 \mathrm{E}-4$ & $6 . \mathrm{E}-05$ \\
\hline 11 & $7.1 \mathrm{E}-06$ & $1.5 \mathrm{E}-05$ & $7 E-06$ & $4.1 \mathrm{E}-3$ & $3.7 \mathrm{E}-2$ & $4.1 \mathrm{E}-06$ & $1.3 \mathrm{E}-3$ & $4.2 \mathrm{E}-3$ & 0.06 & $1.8 \mathrm{E}-07$ & 0.02 & $1.6 \mathrm{E}-07$ & $1 \mathrm{E}-4$ & $5.3 \mathrm{E}-05$ \\
\hline 12 & $5.9 \mathrm{E}-05$ & $1.6 \mathrm{E}-05$ & $6 \mathrm{E}-06$ & $2.1 \mathrm{E}-3$ & $3.7 \mathrm{E}-2$ & $3 \mathrm{E}-06$ & $1 \mathrm{E}-3$ & $4.1 \mathrm{E}-3$ & 0.1 & $1.8 \mathrm{E}-07$ & 0.01 & $2.7 \mathrm{E}-07$ & $2 \mathrm{E}-4$ & $5.1 \mathrm{E}-05$ \\
\hline $\min$ & $7.1 \mathrm{E}-06$ & $1.4 \mathrm{E}-06$ & $6 \mathrm{E}-07$ & $1 E-3$ & $3.7 \mathrm{E}-2$ & $4.8 \mathrm{E}-07$ & $4.5 \mathrm{E}-05$ & $7 E-4$ & $5.4 \mathrm{E}-3$ & $2.9 \mathrm{E}-08$ & 0.01 & $4.8 \mathrm{E}-09$ & $2 \mathrm{E}-05$ & 3.E-06 \\
\hline $\max$ & $4.8 \mathrm{E}-4$ & $2.4 \mathrm{E}-05$ & $1 E-05$ & $1.3 \mathrm{E}-2$ & 2.6 & $8.2 \mathrm{E}-06$ & $1.85 \mathrm{E}-3$ & $3.9 \mathrm{E}-2$ & 3.0 & $3.4 \mathrm{E}-05$ & 0.6 & $5.8 \mathrm{E}-07$ & $1.3 \mathrm{E}-3$ & $6 . \mathrm{E}-05$ \\
\hline mean & $8.9 \mathrm{E}-05$ & $1.2 \mathrm{E}-05$ & $6 E-06$ & $4.8 \mathrm{E}-3$ & 0.4 & $3 E-06$ & $7.3 \mathrm{E}-4$ & $7.7 \mathrm{E}-3$ & 0.3 & $3.0 \mathrm{E}-06$ & 0.07 & $1.2 \mathrm{E}-07$ & $3 E-4$ & $3 . E-05$ \\
\hline
\end{tabular}

ranged from -61.2 to 43.42 . All the samples show low ecological risk index, this indicates low polluted according to (Hakanson, 1980).

\subsubsection{Pollution Load Index (PLI)}

This index is a quick tool in order to compare the pollution status of different places (Adebowale et al., 2009). The values of Pollution Load Index are $<1$ which is indicative that there is no pollution as shown in Figure 18. These results attributed principally to natural sources.

\subsubsection{Geo-Accumulation Index Igeo}

Geo-accumulation index Igeo, is a quantitative measure of the degree of pollution in groundwater as shown in Table 9 presents the indices for the quantification of trace metal accumulation in the Akwa-Mundemba (Singh et al., 1997). The values range as in Table 4. Groundwater is unpolluted to strongly polluted by $\mathrm{Fe}$ in samples $3,5 \& 7$ and $\mathrm{Zn}$ in samples $3,4 \& 7$; while it is unpolluted to moderately polluted by $\mathrm{Sr}$ in all 12 samples. The other eleven trace metals are not polluting the groundwater in Akwa-Mundemba area.

The summary of results for the evaluation of pollution indices is presented in Table 10.

The mostly neutral $\mathrm{pH}$, low temperatures, low TDS, low EC and the short residence time of ground water due to high gradients; are conditions unfavourable for trace metal oxidation and dissolution in groundwater. This implies that conditions are unfavourable for the accumulation of the trace metals in the fluid phase. A reason for the absence of high concentrations of trace metals in groundwater of 


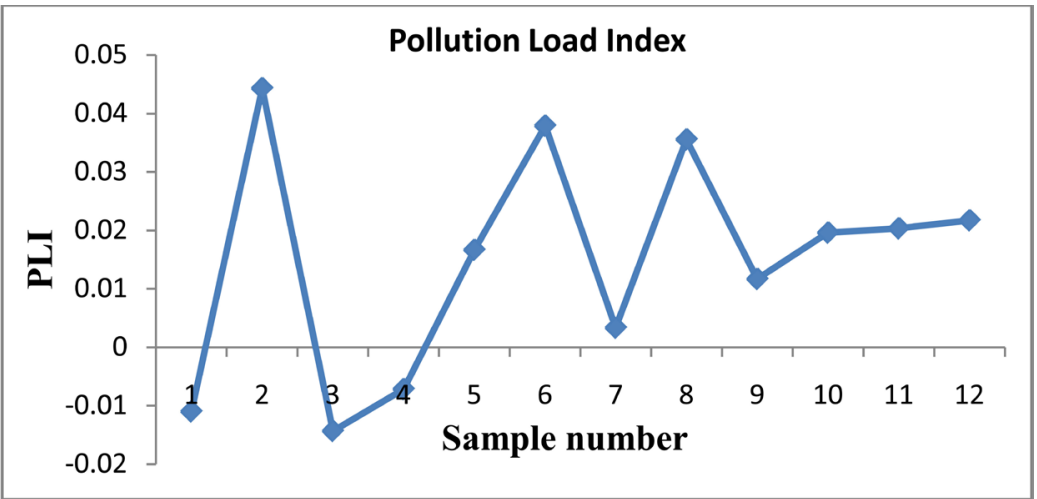

Figure 18. The pollution load index for trace metalof groundwater in Mudemba.

Table 10. Summary Classification of Akwa-Mundemba groundwater based on pollution evaluation indices.

\begin{tabular}{ccccc}
\hline Index & Range & Classification & SN & $\%$ \\
\hline DC & $<10$ & Low degree of contamination factor & 12 & 100 \\
& $\leq 1$ & Background contamination & 4 & 33.4 \\
& $1-2$ & Minimal enrichment & 1 & 8.3 \\
EF & $2-5$ & Moderate enrichment & 1 & 8.3 \\
& $5-20$ & Significant enrichment & 5 & 41.7 \\
& $20-40$ & Very high enrichment & 1 & 8.3 \\
Er & $<40$ & Low potential risk & 12 & 100 \\
RI & $<150$ & Low ecological risk & 12 & 100 \\
PLI & $<1$ & No pollution & 12 & 100 \\
& $\leq 0$ & No-pollution & Pb, Co, Cu, Cr, Mn, Sr, Cd, V, Ni, As, Li, Ba, Mn \\
& $0-1$ & No pollution to moderately pollution & Sr, Fe, Zn & \\
Igeo & $1-2$ & Moderately pollution to pollution & Fe, Zn & \\
& $2-3$ & Pollution to strong pollution & Fe, Zn & \\
& & & & \\
\hline
\end{tabular}

Akwa-Mundemba though they may be present in the parent rock and soil.

The concentrations of trace metals in groundwater have also been reported below guidelines in Shanghai, China (Xu et al., 2004); Tuscany, Italy (Tamasi \& Cini, 2004); and USA (Thomas et al., 1998).

\section{Conclusion}

The groundwater in the Akwa-Mundemba area presents no pollution risks or hazards.

The degree of contamination and contamination factors such as the ER, EF, PLI and Igeo had low values of trace metals indicating that, the groundwater is unpolluted with trace metals but trace metals are being enriched. Thus, from health risk indices and pollution evaluation indices of trace metals, the groundwater in Akwa-Mundemba area is safe for drinking. 
The enrichment factors show that the sources of the trace metals are from geogenic and anthropogenic processes. Arsenic, Lead and Vanadium are enriched although they fall below the hazard risk values; this shows they have pollution potential that could be attributed to weathering and agricultural wastes.

The severity of metal toxicity is governed by several factors, such as dose, nutrition, age, and even life style. Therefore, these low trends might not guarantee the complete absence of human health risks. Generally, from risk assessment on trace metals using risk indices in the analyzed groundwater samples might not cause any health risk. However, due to an increasing level of environmental pollution that might be imposed by increasing human activity in this area, groundwater sources might become a potential sink of contaminants; this is significant reason that makes constant monitoring, implementation and treatment of groundwater for drinking purposes necessary.

The trace metal concentrations in the study are within WHO permissible limits except that of iron which are above permissible limits.

The high iron concentrations could be attributed to the presence of rocks containing high concentrations of magnetite and hematite.

\section{Conflicts of Interest}

The authors declare no conflicts of interest regarding the publication of this paper.

\section{References}

Adebowale, K. O., Agunbide, F. O., \& OluOwolabi, B. (2009). Trace Metal Concentration, Site Variations and Partitioning Pattern in Water and Bottom Sediments from Coastal Area: A Case Study of Ondo Coast, Nigeria. Environmental Research Journal, 3, 46.

Agunbiade, F. O., Olu-Owolabi, B. I., \& Adebowale, K. O. (2009). Phytoremediation Potential of Eichornia crassipes in Metal Contaminated Coastal Water. Bioresource Technology, 100, 4521-4526. https://doi.org/10.1016/j.biortech.2009.04.011

Akoachere, R. A., Etone, E. N., Mbua, R. L., Ngassam, M. P., Longonje, S. N., Oben, P. M., \& Engome, R. W. (2019). Trace Metals in Groundwater of the South Eastern Piedmont Region of Mount Cameroon: Quantification and Health Risk Assessment. Open Access Library Journal, 6, 1-21. https://doi.org/10.4236/oalib.1105327

Cameroon Pamol Plantation. Weather Station Data (2005-2008) (p. 36).

Dumort, J. C. (1968). Reconnaissance Geologic Map of Douala-West (1:500000) and EXplanatory Notes (p. 69). Federal Republic of Cameroon, Directorate of Mines and Geology Cameroun.

Edet, A. E., \& Offiong, O. E. (2002). Evaluation of Water Quality Pollution Indices for Heavy Metal Contamination Monitoring: A Study Case from Akpabuyo-Odukpani Area Lower Cross River Basin (Southeastern Nigeria). GeoJournal, 57, 295-304. https://doi.org/10.1023/B:GEJO.0000007250.92458.de

Fairhead, J. D., \& Binks, R. M. (1991). Differential Opening of the Central and South Atlantic Oceans and the Opening of the West African System. Tectonophysics, 187, 191-203. https://doi.org/10.1016/0040-1951(91)90419-S

Fitton, J. D. (1980). The Benue Trough and the Cameroon Line-A Migrating Rift System 
in West Africa. Earth and Planetary Science Letters, 51, 132-138. https://doi.org/10.1016/0012-821X(80)90261-7

Fitton, J. D., \& Dunlop, H. M. (1985). The Cameroon Line, West Africa and Its Bearing on the Origin of Oceanic and Continental Alkali Basalts. Earth and Planetary Science Letters, 72, 23-38. https://doi.org/10.1016/0012-821X(85)90114-1

Hakanson, L. (1980). An Ecological Risk Index for Aquatic Pollution Control: A Sedimentological Approach. Water Research, 14, 975-1001. https://doi.org/10.1016/0043-1354(80)90143-8

Halliday, A. N., Davidson, J. P., Holden, P., Dewolf, C. P., Lee, D. C., \& Fitton, D. G. (1990). Trace Element Fractionation in Plume and the Origin of HIMU Mantle beneath the Cameroon Line. Nature, 347, 523-528. https://doi.org/10.1038/347523a0

Halliday, A. N., Dicken, A. P., Fallick, A. E., \& Fitton, J. D. (1988). Mantle Dynamics: A $\mathrm{Nd}, \mathrm{Sr}, \mathrm{Pb}$ and $\mathrm{Os}$ Isotope Study of the Cameroon Line Volcanic Chain. Journal of Petrology, 29, 181-211. https://doi.org/10.1093/petrology/29.1.181

Harikumar, P. S., Nasir, U. P., \& Rahman, M. M. (2009). Distribution of Heavy Metals in the Core Sediments of a Tropical Wetland System. International Journal of Environmental Science \& Technology, 6, 225-232. https://doi.org/10.1007/BF03327626

Hu, X., Zhang, Y., Ding, Z. H., Wang, T. J., Lian, H. Z., \& Sun, Y. Y. (2012). Bio-Accessibility and Health Risk of Arsenic and Heavy Metals (Cd, Co, Cr, Cu, Ni, Pb, Zn and Mn) in TSP and PM2.5 in Nanjing, China. Atmospheric Environment, 57, 146-152. https://doi.org/10.1016/j.atmosenv.2012.04.056

Ji, C., Kwon, E., Nga, L., Myung, C., Jung, E., Georges, E., Mbome. L. I., \& Ki-Hyun, K. (2012). Impact Assessment of Heavy Metal Pollution in the Municipal Lake Water, Yaounde, Cameroon. Geosciences Journal, 16, 193-202. https://doi.org/10.1007/s12303-012-0012-9

Kamunda, C., Mathuthu, M., \& Madhuku, M. (2016). Health Risk Assessment of Heavy Metals in Soils from Witwatersrand Gold Mining Basin, South Africa. International Journal of Environmental Research and Public Health, 13, pii: E663. https://doi.org/10.3390/ijerph13070663

Kim, E. J., Herrera, J. E., Huggins, D., Braam, J., \& Koshowki, S. (2011). Effect of pH on the Concentrations of Lead and Trace Contaminants in Drinking Water: A Combined Batch, Pipe Loop and Sentinel Home Study. Water Research, 45, 2763-2774. https://doi.org/10.1016/j.watres.2011.02.023

Koki, I. B., Bayero, A. S., Umar, A., \& Yosuf, S. (2015). Health Risk Assessment of Heavy Metals in Water, Air, Soil and Fish. African Journal of Pure and Applied Chemistry, 9, 204-210. https://doi.org/10.5897/AJPAC2015.0654

Kolluru, R. V., Bartell, S. M., Pitblado, R. M., \& Stricoff, R. S. (1996). Risk Assessment and Management Handbook. New York: McGraw-Hill.

Liaghati, T., Preda, M., \& Cox, M. (2003). Heavy Metal Distribution and Controlling Factors within Coastal Plain Sediments, Bells, Creek Catchment, Southeast Queensland, Australia. Environment International, 29, 935-948.

https://doi.org/10.1016/S0160-4120(03)00060-6

Lushenko, M. A. (2010). A Risk Assessment for Ingestion of Toxic Chemicals in Fish from Imperial Beach. San Diego, CA: San Diego State University.

Mehri, A., \& Marjan, R. F. (2013). Trace Metals in Human Nutrition: A Review. International Journal of Medical Investigation, 2, 115-128.

Mundemba Monographic Study 2010 (p. 128).

Ngako, V., Njonfang, E., Aka, F. T., Affaton, P., \& Metuk Nnange, J. (2006). The North-South 
Paleozoic to Quaternary Trend of Alkaline Magnetism from Niger to Cameroon: Complex Interaction between Hotspots and Precambrian Faults. Journal of African Earth Science, 45, 241-256. https://doi.org/10.1016/j.jafrearsci.2006.03.003

Nono, A., Njonfang, E., Kagou Dongmo, A., Nkouathio, D. G., \& Tchoua, F. M. (2004). Pyroclastic Deposits of the Bambouto Volcano (Cameroon Line, Central Africa): Evidence of a Strombolian Initial Phase. Journal of African Earth Science, 39, 409-414. https://doi.org/10.1016/j.jafrearsci.2004.07.026

Paustenbach, D. J. (2002). Human and Ecological Risk Assessment: Theory and Practice. New York: John Wiley and Sons.

Poudjom Djomani, Y. H., Diament, M., \& Wilson, M. (1997). Lithospheric Structure across the 1159 Adamawa Plateau (Cameroon) from Gravity Studies. Tectonophysics, 273, 317-327. https://doi.org/10.1016/S0040-1951(96)00280-6

Singh, M., Ansari, A. A., Müller, G., \& Singh, I. B. (1997). Heavy Metals in Freshly Deposited Sediments of the Gomati River (a Tributary of the Ganga River): Effects of Human Activities. Environmental Geology, 29, 246-252. https://doi.org/10.1007/s002540050123

Smith, A., \& Livermore, R. A. (1991). Pangeain Permian to Jurassic Time. Tectonophysics, 187, 135-179. https://doi.org/10.1016/0040-1951(91)90417-Q

Song, D., Zhuang, D., Jiang, D., Fu, J., \& Wang, Q. (2015). Integrated Health Risk Assessment of Heavy Metals in Suxian County, South China. International Journal of Environmental Research and Public Health, 12, 7100-7117. https://doi.org/10.3390/ijerph120707100

Tamasi, G., \& Cini, R. (2004). Heavy Metals in Drinking Water from Mount Amiata, Possible Risk from Arsenic for Public Health in the Province of Siena. Science of the Total Environment, 327, 41-51. https://doi.org/10.1016/j.scitotenv.2003.10.011

Thomas, F., Mallick, C., Endreszl, E. C., \& Davies, K. S. (1998). District Responses to Copper Stress in the Halophyte, Mesembryanthemum crystallinum. Physiologia Plantarum, 102, 360-368. https://doi.org/10.1034/j.1399-3054.1998.1020304.x

Ubangoh, R. U. (1998). Estudo paleomagnético do vulcanismo terciário da Republica dos Camarões. PhD Thesis, São Paulo.

United States Environmental Protection Agency USEPA (2012). Waste and Clean up Risk Assessment. http://www2.epa.gov/risk/waste-and-cleanup-risk-assessment

Verma, R., \& Dwivedi, P. (2013). Heavy Metal Water Pollution-A Case Study. Recent Research in Science and Technology, 5, 98-99.

WHO (2011). Guidelines for Drinking-Water Quality (pp. 1-541).

Xu, Y. J., Liu, X. Z., \& Ma, A. J. (2004). Current Research on Toxicity Effect on Molecular Mechanisms of Heavy Metals on Fish. Marine Science, 28, 67-70.

Zhang, L. P., Ye, X., \& Feng, H. (2007). Heavy Metal Contamination in Western Xiamen Bay Sediments and Its Vicinity, China. Marine Pollution Bulletin, 54, 974-982. https://doi.org/10.1016/j.marpolbul.2007.02.010 